\title{
Bioactivity, Bioavailability and Bioaccessibility of Blackcurrant Anthocyanins: An Updated Comprehensive Review
}

\section{Ruiting Li ${ }^{1}$, Chunmin Yang ${ }^{1}$, Bin Xue ${ }^{1}$, Xiaodan $\mathrm{Hui}^{2}$, Xin Shao ${ }^{2 *}$ and Gang $\mathbf{W u}^{2 *}$}

${ }^{1}$ School of Engineering, Guangzhou College of Technology and Business, Guangzhou, China

${ }^{2}$ Department of Critical Care Medicine, Maoming People's Hospital, Maoming, Guangdong, China

*Corresponding Author: Xin Shao and Gang Wu, Department of Critical Care Medicine, Maoming People's Hospital, Maoming, Guangdong, China.

DOI: $10.31080 /$ ASNH.2022.06.1005
Received: January 17, 2022

Published: February 10, 2022

(C) All rights are reserved by Xin Shao, Gang

Wu., et al.

\begin{abstract}
Blackcurrant-based products are trending worldwide as potential functional foods consumed for diseases prevention. Blackcurrant is recognized as its abundant sources of bioactive compounds and dietary fiber. The phenolic compounds, especially proanthocyanins and anthocyanins existing in blackcurrant berry fruit, have been extensively studied by the scientific community for their various medicinal values. The benefits of the anthocyanins are associated with their free-radical scavenging capacity. Anthocyanins must be available or removed from the blackcurrant matrix and then bioaccessible in the gastrointestinal system and must pass through metabolism to the targeted tissue for this capability in humans or animals. This review was focused on the anthocyanin metabolism from the blackcurrant, including the bioavailability, bioaccessibility, and bioactivity, by summarizing factors affecting phytochemical profiles of blackcurrant-based products, including growing and processing and biokinetics of blackcurrant anthocyanins. Assessment of bioaccessibility and bioavailability of blackcurrant anthocyanin is important for understanding its limitations on absorption and functions of blackcurrant anthocyanin towards human nutrition.
\end{abstract}

Keywords: Anthocyanin; Bioavailability; Blackcurrant; Phenolic Compounds; Functional Foods

\section{Introduction}

Traditionally, blackcurrant is used as a natural food colorant and dye due to its high level of colored pigments content and is even used as medicine to treat various diseases [117]. Commercially, blackcurrant is grown mainly for juice production, and an increasing number of blackcurrant-containing products are available on the market [69]. The obtained blackcurrant juice or juice concentrate is abundant in polyphenols, especially proanthocyanins and anthocyanins [26]. The juiceproducing byproduct (pomace) is known as an affluent source of bioactive compounds and dietary fiber $[5,78,89,121,116]$.
The phenolic compounds, especially proanthocyanins and anthocyanins existing in blackcurrant berry fruit, have been extensively studied by the scientific community for their various medicinal values, such as antioxidant activity [55,72,73,114,129], anti-inflammatory activity $[12,65,74,90,101,106,122]$, neuroprotective actions [38,115,123,127,146,147,148], anti-obesity properties $[10,24,50,58,64,61,60,75,107,128$,$] , anti-cancer properties$ $[33,76,80,95,96,105]$, indicating that blackcurrant can be used as a potential pharmaceutical ingredient [100]. Blackcurrant-based products are trending worldwide as potential functional foods consumed to prevent diseases [26]. 
Anthocyanin is the main responsible compound in blackcurrant to have potential health benefits. The compound is biologically and pharmacologically capable of being antimicrobials, reducing oxidative stress, and counteracting the development of numerous noncommunicable illnesses, according to in vitro, animal, and clinical studies [85]. The beneficial health of the anthocyanins is also associated with their free-radical scavenging capacity. Anthocyanins need to be available or extracted from the blackcurrant matrix and then become bioaccessible in the gastrointestinal system, extending into the target tissue to have this capacity in humans or animals [37]. These processes are called bioaccessibility and bioavailability of anthocyanins.

The assessment of bioaccessibility and bioavailability is important for understanding of the relationship between food and nutrition [85]. Therefore, this review focused on the anthocyanin metabolism from the blackcurrant, including bioavailability, bioaccessibility and bioactivity, by summarizing factors affecting phytochemical profiles of blackcurrant-based products, including growing and processing and biokinetic of blackcurrant anthocyanins. Development of blackcurrant-based ingredients and food products and their future potential applications were also be reviewed. Understanding this mechanism is important to enhance the efficacy of compounds from various processed products of blackcurrant.

\section{Chemical profiles of blackcurrant}

Bioactive profiles of blackcurrant berry, juice (concentrate) or extracts, and pomace

The product tree of the blackcurrant products and their processing has been shown in figure 1. Blackcurrants can be processed to be a variety of berry products, e.g., juice [53], extract $[23,135]$, juice fortified [139], polyphenol-rich drink [19], polyphenol nectars [24].

The processed products with the content of anthocyanin, polyphenols and ascorbic acid are described to have potential health benefits, as overviewed in table 1. Products processed in juice, drink and nectars have polyphenols and ascorbic acid as the effective compounds on the health benefits, e.g., anti-atherosclerosis [53] and hypoglycemic response [138]. The intake of black currant juice with high ascorbic acid content and free radical-scavenging capacity in plasma enhances the state of postprandial antioxidant [53] in addition to postprandial glycemic control [138]. The polyphenol intake reduces the postprandial glycemic associated with intestinal glucose inhibition [19]. The inhibition of intestinal absorption of glucose is also found in the blackcurrant nectars containing high polyphenols [138]. Furthermore, in the blackcurrant extract, anthocyanins play role in the main benefits of blackcurrant consumption for cardiovascular protection, cognitive performance, repairment of endothelial dysfunction, and fat oxidation increase. Cook., et al. [24] reported that cardiovascular responses, muscle oxygen saturation, muscle activity were modified and enhanced fat oxidation with the anthocyanin during a cycle of 120 minutes at 65\% CO2 max in endurance-trained male cyclists, following ingestion of blackcurrant extracts for 7 days. Consumption of blackcurrant extracts improves cognitive performance and mood as the anthocyanin substantially alters the neuroendocrinological and cognitive benefits conveyed [146]. Besides the clinical report, few studies reported that the blackcurrant extracts have benefits on sport performance, as shown in table 2 . The anthocyanin improves team sports performance with repeated maximal sprints [149], the sprint performance of football players [45], exercise performance [23], the overall performance of cycling [94] and climbing performance [113]. The consumption of blackcurrant extract influences physiological responses and does not have detrimental side effects [113].

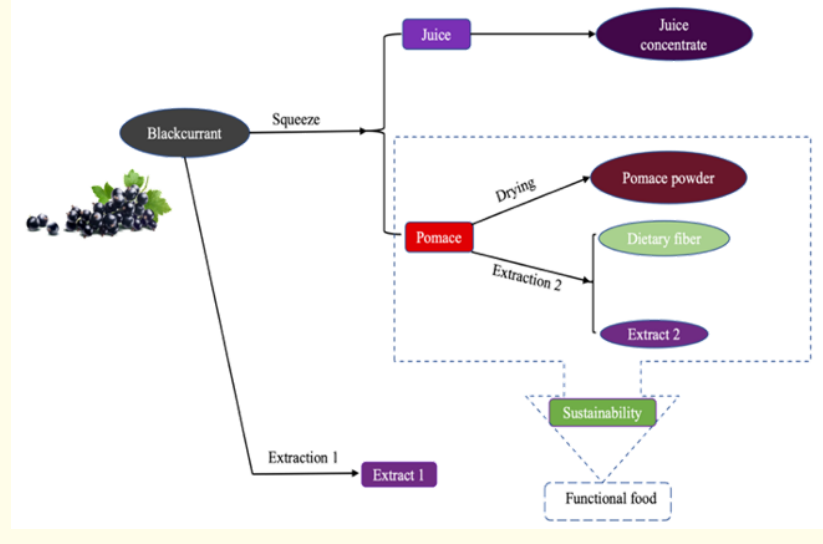

Figure 1: The diagram of blackcurrant processing. 


\begin{tabular}{|c|c|c|c|c|c|}
\hline Main benefits & Materials & Effective factors & Main methodologies & Conclusions & Reference \\
\hline $\begin{array}{l}\text { Anti-atheroscle- } \\
\text { rosis }\end{array}$ & $\begin{array}{l}\text { blackcurrant } \\
\text { (BC) juice }\end{array}$ & $\begin{array}{l}\text { Polyphenols and } \\
\text { ascorbic acid }\end{array}$ & $\begin{array}{l}\text { In human subjects with } \\
\text { an atherosclerosis-prone } \\
\text { phenotype (after con- } \\
\text { sumption of a high-energy } \\
\text { meal). }\end{array}$ & $\begin{array}{l}\text { Blackcurrant juice consumption } \\
\text { may improve postprandial an- } \\
\text { tioxidant status as indicated by } \\
\text { higher ascorbic acid levels and } \\
\text { free radical-scavenging capacity } \\
\text { in plasma. }\end{array}$ & $\begin{array}{c}\text { Huebbe., et al. } \\
\text { [53] }\end{array}$ \\
\hline \multirow[t]{2}{*}{$\begin{array}{l}\text { Cardiovascular } \\
\text { protection }\end{array}$} & $\begin{array}{c}\text { blackcurrant } \\
\text { extract }\end{array}$ & Anthocyanins & $\begin{array}{l}\text { Cardiovascular function } \\
\text { (i.e., blood pressure, heart } \\
\text { rate, ejection time, cardiac } \\
\text { output, stroke volume, and } \\
\text { total peripheral resis- } \\
\text { tance) during supine rest } \\
\text { was examined }\end{array}$ & $\begin{array}{l}\text { 7-days intake of New Zealand } \\
\text { blackcurrant extract demonstrat- } \\
\text { ed dose-dependent changes on } \\
\text { some cardiovascular parameters } \\
\text { during supine rest in endurance- } \\
\text { trained male cyclists. }\end{array}$ & $\begin{array}{c}\text { Cook., et al. } \\
\text { [22] }\end{array}$ \\
\hline & $\begin{array}{c}\text { blackcurrant } \\
\text { extract }\end{array}$ & Anthocyanins & $\begin{array}{l}\text { The effect of 7-day intake } \\
\text { of New Zealand blackcur- } \\
\text { rant extract on arterial } \\
\text { functions, e.g., arterial } \\
\text { stiffness, and serum lipids. }\end{array}$ & $\begin{array}{l}\text { Short-term New Zealand black- } \\
\text { currant intake reduces central } \\
\text { arterial stiffness and central } \\
\text { blood pressure in older adults. } \\
\text { Anthocyanin-rich blackcurrants } \\
\text { might be beneficial for maintain- } \\
\text { ing or improving cardiovascular } \\
\text { health as an alternative to phar- } \\
\text { maceutical medications. }\end{array}$ & $\begin{array}{l}\text { Okamoto., et } \\
\text { al. [102] }\end{array}$ \\
\hline \multirow[t]{3}{*}{$\begin{array}{l}\text { Cognitive perfor- } \\
\text { mance }\end{array}$} & $\begin{array}{c}\text { blackcurrant } \\
\text { extract }\end{array}$ & Anthocyanins & $\begin{array}{l}\text { The effects of two } \\
\text { blackcurrant extracts on } \\
\text { cognitive outcomes, mood, } \\
\text { autonomic measures, } \\
\text { peripheral and central } \\
\text { monoamine tone, and an- } \\
\text { thocyanin bioavailability } \\
\text { to plasma. }\end{array}$ & $\begin{array}{l}\text { A cognitive benefit of acute } \\
\text { blackcurrant supplementa- } \\
\text { tion in healthy young humans } \\
\text { and the first description of a } \\
\text { clinically significant inhibition } \\
\text { of monoamine oxidase-B and } \\
\text { monoamine oxidase-A using a } \\
\text { commonly consumed fruit. } \\
\text { Compounds other than antho- } \\
\text { cyanins may be responsible for } \\
\text { the observed in vivo monoamine } \\
\text { oxidase inhibition and that the } \\
\text { degree of processing and the } \\
\text { cultivar of blackcurrant fruit } \\
\text { used substantially alter the neu- } \\
\text { roendocrinological and cognitive } \\
\text { benefits conveyed. }\end{array}$ & $\begin{array}{c}\text { Watson., et al. } \\
{[146]}\end{array}$ \\
\hline & $\begin{array}{l}\text { blackcurrant } \\
\text { anthocyanins }\end{array}$ & Anthocyanins & $\begin{array}{l}\text { The changes of IGF- } 1 \text { be- } \\
\text { fore and after the supple- } \\
\text { mentation }\end{array}$ & $\begin{array}{c}\text { The blackcurrant anthocyanin } \\
\text { has the potential to be developed } \\
\text { to treat neurological conditions } \\
\text { with IGF-1 deficiency. }\end{array}$ & $\begin{array}{l}\text { Fan., et al. } \\
\quad[38]\end{array}$ \\
\hline & $\begin{array}{c}\text { blackcurrant } \\
\text { extract }\end{array}$ & Anthocyanins & $\begin{array}{l}\text { The influence of the acute } \\
\text { administration of antho- } \\
\text { cyanin-rich blackcurrant } \\
\text { juice, standardized at } 500 \\
\text { mg of polyphenols, on } \\
\text { mood and attention }\end{array}$ & $\begin{array}{l}\text { Highlighting an anxiolytic effect } \\
\text { of the consumption of a single } \\
\text { serve blackcurrant juice, and an } \\
\text { indication of greater alertness } \\
\text { and lower fatigue in healthy } \\
\text { young adults. } \\
\text { These changes did not improve } \\
\text { cognitive performance and } \\
\text { slowed responses in the choice } \\
\text { reaction time task }\end{array}$ & $\begin{array}{c}\text { Watson., et al. } \\
\text { [147] }\end{array}$ \\
\hline
\end{tabular}




\begin{tabular}{|c|c|c|c|c|c|}
\hline Main benefits & Materials & Effective factors & Main methodologies & Conclusions & Reference \\
\hline \multirow[t]{4}{*}{$\begin{array}{l}\text { Hypoglycemic } \\
\text { response }\end{array}$} & $\begin{array}{l}\text { A basic black- } \\
\text { currant juice } \\
\text { and a black- } \\
\text { currant juice } \\
\text { fortified with } \\
\text { crowberry } \\
\text { powder }\end{array}$ & $\begin{array}{l}\text { Bioactive polyphe- } \\
\text { nols }\end{array}$ & $\begin{array}{l}\text { Evaluate postprandial } \\
\text { glycemic responses to a } \\
\text { basic blackcurrant juice } \\
\text { and a blackcurrant juice } \\
\text { fortified with crowberry } \\
\text { powder (respective poly- } \\
\text { phenol contents } 159 \text { and } \\
293 \mathrm{mg} / 100 \mathrm{~mL} \text { ), both } \\
\text { sweetened with sucrose. }\end{array}$ & $\begin{array}{l}\text { Fortification of blackcur- } \\
\text { rant juice with crowberry } \\
\text { doubled the polyphenol } \\
\text { content and improved post- } \\
\text { prandial glycemic control in } \\
\text { healthy subjects. }\end{array}$ & $\begin{array}{l}\text { Torronen., } \\
\text { et al. [140] }\end{array}$ \\
\hline & Blackcurrant & Anthocyanins & $\begin{array}{l}\text { Determine the dose } \\
\text { dependent effects of } \\
\text { blackcurrant extract on } \\
\text { postprandial glycemia. }\end{array}$ & $\begin{array}{l}\text { Consumption of blackcur- } \\
\text { rant extract in amounts } \\
\text { roughly equivalent to } 100 \\
\text { g of blackcurrants reduced } \\
\text { postprandial glycemia, } \\
\text { insulinemia and incretin } \\
\text { secretion. }\end{array}$ & $\begin{array}{l}\text { Castro-Acos- } \\
\text { ta., et al. [18] }\end{array}$ \\
\hline & $\begin{array}{c}\text { Apple and } \\
\text { blackcurrant } \\
\text { polyphenol-rich } \\
\text { drinks }\end{array}$ & $\begin{array}{l}\text { Combinations of } \\
\text { polyphenols may } \\
\text { be particularly } \\
\text { effective through } \\
\text { complementary } \\
\text { mechanisms }\end{array}$ & $\begin{array}{l}\text { A randomized, controlled, } \\
\text { double-blinded cross-over } \\
\text { trial was conducted in } \\
\text { healthy volunteers. }\end{array}$ & $\begin{array}{c}\text { Ingestion of apple and } \\
\text { blackcurrant polyphenols } \\
\text { decreased postprandial gly- } \\
\text { cemia, which may be partly } \\
\text { related to inhibition of } \\
\text { intestinal glucose transport. }\end{array}$ & $\begin{array}{l}\text { Castro-Acos- } \\
\text { ta., et al. [20] }\end{array}$ \\
\hline & $\begin{array}{l}\text { Blackcurrant } \\
\text { nectars }\end{array}$ & Polyphenols & $\begin{array}{l}\text { A total of } 18 \text { healthy } \\
\text { volunteers participated in } \\
\text { a randomized, controlled, } \\
\text { cross-over study. } \\
\text { Blood samples were } \\
\text { collected at fasting and } \\
\text { six times postprandially } \\
\text { during } 120 \text { min. }\end{array}$ & $\begin{array}{l}\text { The attenuated glycemic } \\
\text { response after the black- } \\
\text { currant nectar may be } \\
\text { explained by inhibition of } \\
\text { intestinal absorption of } \\
\text { glucose by blackcurrant } \\
\text { anthocyanins. }\end{array}$ & $\begin{array}{c}\text { Torronen., et } \\
\text { al. [137] }\end{array}$ \\
\hline
\end{tabular}




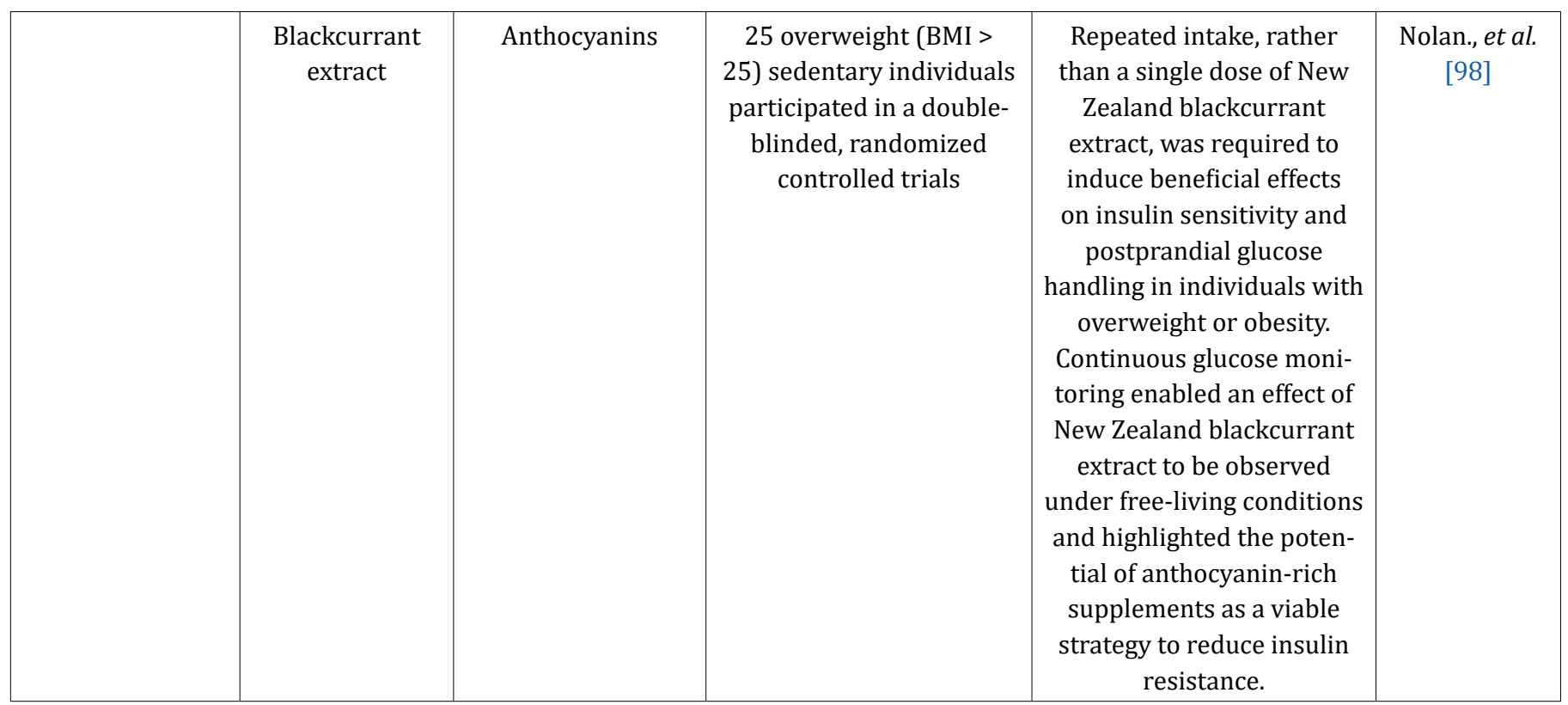

Table 1: Clinical report.

\begin{tabular}{|c|c|c|c|c|}
\hline Sport & Materials & Effective factors & Conclusions & Reference \\
\hline Football & $\begin{array}{c}\text { Blackcurrant } \\
\text { extract }\end{array}$ & Anthocyanins & $\begin{array}{l}\text { New Zealand blackcurrant extract seemed to benefit } \\
\text { repeated sprint performance only in trained football } \\
\text { players. }\end{array}$ & Godwin., et al. [44] \\
\hline Cycling & $\begin{array}{c}\text { Blackcurrant } \\
\text { extract }\end{array}$ & Anthocyanins & $\begin{array}{l}\text { Intake of New Zealand blackcurrant extract for } 7 \text { days } \\
\text { elevated resting concentrations of plasma glycerol, } \\
\text { indicative of higher lipolytic rates. } \\
\text { This may underpin the observed increase in fat oxida- } \\
\text { tion during prolonged cycling in endurance-trained } \\
\text { females. }\end{array}$ & Strauss., et al. [128] \\
\hline Exercise & $\begin{array}{c}\text { Blackcurrant } \\
\text { extract }\end{array}$ & Anthocyanins & $\begin{array}{l}\text { This study provided data to underpin a larger study } \\
\text { designed to evaluate the efficacy of timed blackcurrant } \\
\text { anthocyanins consumption on post-exercise recovery } \\
\text { and innate immunity. }\end{array}$ & Hurst., et al. [55] \\
\hline Cycling & $\begin{array}{c}\text { Blackcurrant } \\
\text { extract }\end{array}$ & Anthocyanins & $\begin{array}{l}7 \text { days intake of New Zealand blackcurrant extract does } \\
\text { not change exercise-induced metabolic responses and } \\
16.1 \mathrm{~km} \text { cycling time trial performance for moderately } \\
\text { endurance-trained men in normobaric hypoxia. }\end{array}$ & Willems., et al. [150] \\
\hline
\end{tabular}




\begin{tabular}{|l|c|c|c|c|}
\hline Exercise & $\begin{array}{c}\text { Blackcurrant } \\
\text { extract }\end{array}$ & Anthocyanins & $\begin{array}{c}\text { Blackcurrant had a small, but significant, effect on } \\
\text { sport performance, with no known detrimental side } \\
\text { effects. }\end{array}$ & Braakhuis., et al. [13] \\
\hline Exercise & $\begin{array}{c}\text { Blackcurrant } \\
\text { extract }\end{array}$ & Anthocyanins & $\begin{array}{c}\text { Daily consumption of blackcurrant anthocyanins for } \\
5 \text { weeks served to enhance the exercise recovery ef- } \\
\text { fectiveness of a single consumption of blackcurrant } \\
\text { anthocyanins and promoted beneficial/protective } \\
\text { antioxidant/anti-inflammatory cellular events that } \\
\text { facilitated exercise recovery. }\end{array}$ & $\begin{array}{c}\text { Hurst., } \text { et al. } \text { [56] } \\
\text { Climbing }\end{array}$ \\
\hline Blackcurrant & Anthocyanins & $\begin{array}{c}\text { Blackcurrant anthocyanin-derived metabolites seemed } \\
\text { to affect physiological responses that facilitate sport } \\
\text { climbing performance. }\end{array}$ & Potter., et al. [113] \\
\hline
\end{tabular}

TABLE 2: Blackcurrant anthocyanins for exercise.

Blackcurrants contain different compositions of anthocyanin and therefore generate possible biological and metabolic impacts [65]. The chemical profiles and functionality of blackcurrant juice (concentrate) and pomace are mainly decided at blackcurrant growing stages and processing strategies.

The intrinsic chemical compositions profiles (vitamins, minerals, and polyphenols) of blackcurrant berry fruits depends on various factors at the growing stage, including, most importantly, genotypes [1,59,84,100,126,134,103], geographical conditions $[84,134,155]$, whether conditions [2]. For instance, blackcurrant cultivars in New Zealand have about 1.5 times more anthocyanins due to their exposure to UV light. Interestingly, Khoo., et al. [63] found that the application of pesticide treatment impacted the phytochemical profiles of blackcurrant berry fruits. Piechowiak, Balawejder [112] reported that ozonation treatment could change the total phenolic content of blackcurrant berry fruit after exposure at different concentrations for a specific duration.

For all the blackcurrant-containing products, their chemical components are affected by different processing strategies. Enzyme treatment [68], high-pressure treatment [141], microwave treatment [89], ozonation treatment [112], pulse electric field treatment [42], supercritical carbon dioxide extraction [7], and ultra sound treatment [41], in singular or in combination $[7,8,118]$, were reported as promising strategies to improve the rate of juice or the recovery of the bioactive compounds from the matrix.

Additionally, solvents applied for extraction, and providing acidic conditions were decisive factors for the chemical compo- nents and extracts stability [4,40,72,100,117]. Nour., et al. [100] compared the effects of the different ratio (40\%,60\%, and 90\%) of organic solvent (ethanol) on the blackcurrant anthocyanins extraction rates and concluded that $60 \%$ was of the highest number in terms of the concentration of the four major anthocyanins. Lee., et al. [72] reported that ethanol was favored than methanol to extract anthocyanins from blackcurrant. For the stability of anthocyanins, it is important to control the $\mathrm{pH}$ (acidic condition). The low stability of anthocyanins in pasteurized juice and frozen pulp causes a difficulty when the juice is being stored due to pigment degradation [31]. The reduction of the pigment degradation can be prevented with the addition of anthocyanin co-factors [14] and the presence of ascorbic acid $[43,77]$. The stabilization of the anthocyanin pigments with $\mathrm{pH}$ control needs to be taken into consideration to prevent discoloration and pigment degradation during manufacturing the blackcurrant berries concentrate.

Unfavorable existence of bitterness and astringency, and sugar addition

Blackcurrants are known for their characteristic bitter and astringent flavor, which is associated with proanthocyanins and anthocyanins [70]. Blackcurrants with substantial quantity of added sugar are often found with pectinolytic enzyme treatments, which increased the perception of bitterness and astringency. The enzymes additionally enhance the average degree of proanthocyanins polymerization [70], while greater levels of proanthocyanins were undesirable owing to their taste. Liu., et al. [79] reported the direct binding of proanthocyanins to oral epithelial cells in vitro. This binding occurs more intensively at higher concentrations, lower $\mathrm{pH}$, and a higher temperature. 
Furthermore, the addition of sugar to the blackcurrant juice influences the perception of the consumers in terms of acidity. Laaksonen., et al. [70] reported the most abundant sugars in the blackcurrant juices are fructose and glucose, and the degradation of sugars was caused by enzymatic treatment. On the other hand, the enzyme-aided juices contain more citric acid, which dominates the acid content in the juices, followed by malic and quinic acids with minor contents, than the non-enzymatic juices. These issues lead to companies concern about gaining health-conscious consumers' attention. In relation to consumer health and liking, therefore, it is important to consider those factors by manipulating the enzymes added during the processing as this compound also has more benefits for the health of consumers.

Anthocyanins, anthocyanidins, and proanthocyanidins

Blackcurrant has a high concentration of flavonoids, in particular anthocyanins, which give a purple color for the blackcurrant [4]. Anthocyanins are a group of water-soluble polyphenols with glycosides, while anthocyanidins are sugar free counterparts of anthocyanins [99]. The edible parts of the fruits include six main anthocyanidins, namely cyanidin (50\%), pelargonidin (12\%), peonidin (12\%), delphinidin (12\%), petunidin (7\%), and malvidin (7\%) [66]. The anthocyanin properties vary depending on the type of berry. The majority of anthocyanidins found in blackcurrant berry fruit are cyanidin and delphinidin, which are glycosylated with glucose or rutinoside during the process of ripening, resulting in the formation of the four major anthocyanins, namely delphinidin 3-0rutinoside (D3R), delphinidin 3-0-glucoside (D3G), cyanidin 3-0glucoside (C3G), and cyanidin 3-O-rutinoside (C3R), accounting for approximately $90 \%$ of blackcurrant total polyphenols content [110]. Figure 2 shows the molecular structures of the four main blackcurrant anthocyanin. This categorization relies on the hydroxyl and methoxyl groups' number and position on the flavanic nucleus. The bulk of anthocyanins are obviously found in rutinoside forms of delphinidin and cyanidin [110]. Proanthocyanidins, often referred to as condensed tannins, are also an important polyphenolic component in the blackcurrants [125].

Anthocyanins have monomeric flavan-3-ols units as common structural units and can be found as oligomers or polymers. The monomers are commonly (+)-catechin or (-)-epicatechin (referred to procyanidins) or (+) -gallocatechin or (-)-epigallocatechin (prodelphinidins). Proanthocyanidin monomers and oligomers are sometimes referred to catechins. The component is characterized as having biochemical and pharmacological actions "pleiotropically", including antioxidant, anti-inflammatory, immune-stimulative, anti-apoptotic, cell cycle arrest inducing, anti-invasive, and anti- angiogenic properties through modulation of multiple signal transduction pathways [29,92].
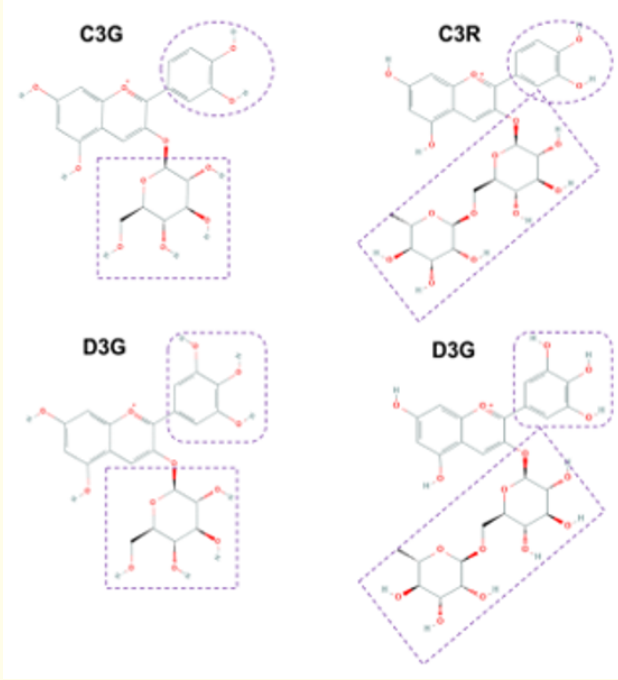

Figure 2: The molecular structures of the four main blackcurrant anthocyanins. Delphinidin 3-0-rutinoside (D3R), Delphinidin 3-0-glucoside (D3G), Cyanidin 3-O-glucoside (C3G), Cyanidin 3-0rutinoside (C3R).

The main phytochemicals in the blackcurrant are these anthocyanins and proanthocyanidins [47], which are effective to be antioxidants [145]. These two classes of flavonoids represent a large part of the total flavonoids consumed in Western foods and have a nutrition and medical interest of their potential protective effects against diseases [145]. The average daily consumption of anthocyanins in the United States is estimated to be $\sim 200$ mg per person, and the average consumption of proanthocyanidins in the United States is estimated to be $58 \mathrm{mg} /$ day [47].

Enzymatic treatments are often employed in the manufacture of juice, particularly in the processing of blackcurrant juices as the juice produces up to $91 \%$ [69]. These treatments also reduce the viscosity of the juice, and enhance bioactive components extraction, such as phenolics. Procyanidins and prodelphinindins in en- 
zymatic maceration are significantly greater with than maceration without enzymes. One potential reason is that the bioactive compounds trapped in the pectin networks are extracted with the enzyme effects.

Naturally hydrophilic anthocyanins have limited potential in foods and cosmetics that include fats or oils. Artificial structure alter hydrophilicity by increasing lipophilicity, making them preferable for lipid-based foods and cosmetics [4,154]. Further studies on $\mathrm{t}$ bioactivity alteration are required.

Biokinetic of blackcurrant anthocyanins - from in vitro bioaccessibility to in vivo bioavailability

Bioaccessibility along with bioavailability are two related but often misunderstood concepts. Bioaccessibility is commonly used to evaluate the amount of nutrient or compound available for absorption after undergoing the digestion process, while bioavailability is the proportion of the nutrient or compound which, after being metabolized and distributed via tissues, reaches the systemic circulation and exerts its effect $[3,46]$. Thus, in vitro simulated gastric intestinal models evaluate bioaccessibility, whereas bioavailability is valued through in vivo studies.

The key issue in investigating the bioavailability of food biocomponents and pharmaceuticals is assessing methods for the three major bioavailability limiting factors: bioaccessibility, absorption, and biomolecule transformation [34]. Variability is considerable between in vitro studies obtained from different methodologies, highlighting the need for standardization. The in vitro methodologies can determine the bioavailability and bioaccessibility of bioactive compounds (simulated gastrointestinal digestion), ex-vivo methodologies (under controlled laboratory conditions, gastrointestinal organs), in-situ methodologies (intestinal perfusion in animals), and in vivo methodologies (studies of humans and animals) [17]. Although in vitro digestion methodologies are most frequently used, in vitro methods have low accuracy compared to in vivo methods because the differences between the biological and actual biological processes in the human body have different conditions. For full measurement of absorption, distribution, metabolism, and excretion of bioactive substances into the human body, in vitro conditions are not accessible, while conditions in vivo tests have biological mechanisms similar to the human body [109]. The in vivo tests are known as initial and most effective tests performed on humans and animals, and are considered as "gold standard" for the assessment of the adsorption, distribution, metabolism, excretion, and toxicity (ADMET) processes.

In order to investigate the bioavailability and potential health impacts of phenolic compounds, in particular anthocyanins, their absorption, metabolism, tissue distribution and excretion, as well as their biochemical activities and interactions with other nutrients are essential to be assessed.

\section{Bioavailability, absorption, and metabolism}

It is arguable in several studies that anthocyanins are absorbed but their absorption rate is depending on their chemical structure, by the dose ingested/administered, and by the food source matrix, one of the main variables impacting stability of anthocyanins. The bioavailability of anthocyanins to absorb the intestines is quite difficult and changes according to processing circumstances and interaction with other compounds, chemical status of the nutrient, release from the food matrix, the food suppressors or co-factor composition, the formation of stable, gradually metabolizing complexes [109]. Mazza., et al. [87] discovered that the human body's absorption of anthocyanin was studied after of a high fat diet was consumed with the ground freeze-dried blueberry in which $75 \%$ of the anthocyanins were identified in blood serum and the presence of them is linked with the rise in serum antioxidant capacity. This study indicates that the anthocyanin can be absorbed in the intact glycosylated form and potentially acylated in human subjects. Exposure to variations in $\mathrm{pH}$, oxygen and a heating combination in vitro significantly reduces the availability of raspberry anthocyanins (extracts) to the serum fraction, although co-digestion with popular foodstuffs (e.g., bread, cooking cereals, ice cream, and cooked mince) may help. Protects the labile anthocyanins and definitely does not decrease the level of serum bioavailability polyphenols [87]. The polyphenols bind the food matrix within the digestion that protecting the unstable anthocyanins from degradation [24]. The artificial food matrix may enhance nutritional stability during storage, boost digestive effectivity, and guarantee optimal dose. Therefore, the selection of food matrix where the compounds are incorporated is important to give an optimal dosage in the human body.

Many investigations have shown that the absorption rate of total or individual anthocyanin was virtually undetected in either 
humans or animals. This may vary in the level of processing of the anthocyanin-containing fruit (freeze-dried blueberry powder versus spray-dried elderberry juice concentrate) and/or in the dietary variations supplemented with anthocyanin-rich material. Table 3 presented the current studies of anthocyanins' absorption from the Vaccinium species derivation. Another stage, that is the quantity of food source or extract supplied, should be addressed to assess the absorption of anthocyanins since the simultaneous intake of other substances may impact the absorption of certain nutrients, xenobiotics, and medicines. Moreover, it was recognized that sources rich in phenolic compounds regulate organic cation intestinal absorption, which was an excellent illustration of food-food interactions, taking into consideration the fact that most vitamins, nutrients, and xenobiotics cross intestinal barriers as organic cations.

On the other hand, bioavailability of anthocyanins related to the dietary sources, in relation to the glycoside type in the molecule. Several studies demonstrated that in rats and humans, anthocyanins are mainly absorbed in their intact forms of glycoside. However, other studies indicated that they were maintained in their aglycone forms $[124,143]$. A review study indicates that aglycones may be absorbed faster than glycosidic forms. Besides, the bioavailability of nonacylated anthocyanins is greater than that of acylated anthocyanins [21]. It is also stated that the glucose transporters such as the glucose transporter 2 (GLUT2) may absorb anthocyanins into the intestinal epithelial cells [39], potentially the cotransporter $\mathrm{Na}+$ /glucose 1 (SGLT1) [144], and actively transported from the intestine and endothelia, where their bioavailability is restricted in circulation [36].

It is recognized that the efficiency of transport and absorption of anthocyanins differed in each type. Other influence variables were the dosage ingested/administered and the period of exposure, depending on the organ/tissue, in addition to the chemical structure were studied. The efficiency of transport may be characterized by more free hydroxyl groups and less OCH3 groups, reducing the bioavailability of anthocyanins. Talavéra., et al. [132] demonstrated that aglycone structure influenced intestinal absorption of anthocyanin induced by the presence of methoxylated groups that reduced intestinal absorption. In addition, a previous study revealed that anthocyanins glycosides were highly absorbed in the stomach due to the favorable environmental condition for their stability. A recent in vitro study using a stomach cell line verified the absorp- tion of anthocyanin and that M3G was evaluated with better transport efficiency in the anthocyanin. Anthocyanins come in touch with various $\mathrm{pH}$ conditions during the passage of anthocyanins via the gastrointestinal tract and may thus occur in different forms. This translates into a rate-limiting step to comprehend the forms of anthocyanin in different parts of the body. Ziberna., et al. [158] suggested that bilitranslocase (organic anion carrier) expressed in the gastric epithelium of rats may be involved in stomach anthocyanin absorption. On the other hand, the transport route of sugar movement may be involved in the absorption of anthocyanins. In human studies, Drakou., et al. [35] concluded that the sugar moiety is a major source of human absorption of dietary flavonoid glycosides, i.e., absorption of aglycones via glucose enhanced, may be through sodium-dependent glucose transport system absorption (SLGT1). Furthermore, an in vitro study suggested the involvement of GLUT2 (the facilitative glucose transporter) in intestinal absorption of anthocyanins.

The cation group's existence seems to affect their intestinal metabolism. Anthocyanins are present in the stomach and intestine in different forms, which are anthocyanins absorption sites [88]. The red flavylium cation form is the form with greater stability in the acidic gastric environment. The flavylium cation, however, is most likely converted to carbinol pseudo, which, after entering the basic environment of the upper small intestine has a limited absorption rate [28]. Their glycosidic forms are hydrolyzed into the colon via microflora, and the aglycones into phenolic acids and/or other unidentified metabolites metabolized [62]. Therefore, the labeling of isotopes of anthocyanins is suggested to evaluate their absorption and metabolism more effectively [81].

In addition, the anthocyanin structure's electron deficit renders anthocyanidins extremely reactive and its stability depends on the $\mathrm{pH}$ and temperature. The nutrients in the gut lumen interact with the anthocyanins and other polyphenols, and create stable complexes with non-heme dietary iron, limiting its absorption in the gut [130]. Nevertheless, the length of time that the anthocyanins are exposed to via food or incubation period in cell experiments seems to be a crucial component in their bioavailability [97]. Despite the fact that anthocyanins have a poor bioavailability when compared to other blackberry polyphenols, these modest amounts of anthocyanins may be bioavailable and well maintained in tissues. Nonetheless, the metabolites produced by the consumption of an- 
thocyanin-rich meals have yet to be fully characterized [49]. There is a chance that undiscovered anthocyanin metabolites are contributing to the observed biologic effects of anthocyanins. However, urine and serum studies [104] (after an oral dosage of 120-230 g of whole berries (fresh weight)) revealed that parent chemicals and their metabolites exhibited comparable kinetic characteristics. Anthocyanins discharged in the urine account for less than $1 \%$ of the entire eaten dosage, according to studies. Relatively urinary excretion is usually employed to establish the minimum absorption rate but, when phenolic chemicals appear in the blood circulation or are strongly excreted in bile and in urine, this parameter for quantitative assessment might lead to an underestimated absorption. Since many of these studies were carried out in animals and cell cultures, further studies including the metabolites of anthocyanins are needed to fully characterize biokinetics of anthocyanins.

\section{Biotransformation}

Prior to consumption, anthocyanins can be biotransformed, which occurs naturally during processing and storage. This transformation resulted in conjugates of anthocyanin-flavan-3-ol. Consequently, the anthocyanins ingested in processed foods might contain different compounds in plants utilized for manufacturing. Anthocyanins are rapidly absorbed into the stomach wall as glycosides after ingestion [132]. The glycosidic forms of anthocyanins can begin metabolic alteration before they are absorbed owing to bacterial digestion of the glycosidic linkage of anthocyanins by the gastrointestinal system. Biological fluids include metabolites of anthocyanins occur predominantly in methylated, glucuronidated, and sulfoconjugated forms.

Certain studies have identified glucuronidated and methylated anthocyanins in human and animal models' urine and blood. The intact glycosidic form reaches the circulatory system rapidly (6 to $20 \mathrm{~min}$ ), and is eliminated in the urine [88]. Anthocyanins are absorbed and distributed as metabolites in human serum and urine. The predominant metabolic reaction with anthocyanins is 0-methylation after gastric absorption [142]. There was no analysis of anthocyanin metabolites in urine, including aglycons and conjugates. The intact substance and its 4'-0-methyl derivatives were only detected [83]. A $721 \mathrm{mg}$ oral C3G dosage was observed in humans, $32.7 \%$ of intact C3G were identified, and an average of $67.3 \%$ of conjugated metabolites were identified in the serum. Bile samples showed that methylated conjugated metabolites of C3G were present, absorbed and further metabolized rapidly [34]. Nevertheless, whereas D3G was the most recovered anthocyanin in bile, it was not discovered in plasma even after 30 min from the aorta. Consequently, C3G gained the methylated form in the liver and tended to be eliminated by bile rather than being distributed into the blood. While rat liver had significant levels of methylated anthocyanins, no [48] traces were found in plasma.

The anthocyanins in blackcurrants may be digested in the gastrointestinal tract, then absorbed into the blood, and finally metabolized. The small intestine only absorbed lower quantities, and most of the anthocyanins are present in the large intestine, where they are metabolized and altered. During the intestine, different enzymes can also modify anthocyanins before entering the blood circulation [120]. Phase I metabolites have been identified as chloroglucinaldehyde,3,4-dihydroxybenzaldehyde, and glucuronidated and methylated cyanidins have been mainly recognized as phase II metabolites [9]. The in vitro and live cell biotransformation of anthocyanins is crucial for evaluating the bioavailability of blackcurrant anthocyanins to maximize their potential for health promotion.

\section{In vitro and in vivo studies of metabolic syndrome}

Blackcurrants are connected to diets high in anthocyanins and have a vital role in health, as well as in treatment and prevention of diseases, such as cardiovascular and metabolic syndrome incidence, including glucose tolerance, dyslipidemia, high blood pressure, abdominal obesity, and insulin resistance, this increases the risk of diabetes and cardiovascular diseases. Most investigations are in vitro studies and only a few studies have been conducted in vivo [30]. This section will review the in vitro and in vivo metabolic syndrome studies as indicated in (Table 3,4 ).

\section{In vitro studies}

Table 3 summarizes the numerous alleged health advantages of blackcurrant conducted in vitro. Kim., et al. [64] revealed the hypocholesterolemia effect of blackcurrant extract, by modulating the genes involved in intestinal cholesterol transport. utilizing Caco-2 cells as an in vitro model. Antibacterial activities on bacteria that ruin food, including Listeria monocytogenes [114], and Salmonella [110]. Blackcurrant extract with rich anthocyanin has an excellent perspective as an antibacterial additive in food. Parkar., et al. [110] has found the inhibitory function of intestinal epithelial cells adhesion in vitro and an increase in the proliferation of gut probiotics (Lactobacillus rhamnosus). Blackcurrant juice can therefore be utilized to control intestinal health. 


\begin{tabular}{|c|c|c|c|c|c|}
\hline Main benefits & Materials & Effective factors & Methods & Conclusions & Reference \\
\hline $\begin{array}{l}\text { Neuroprotec- } \\
\text { tive activity }\end{array}$ & $\begin{array}{c}\text { Blackcurrant } \\
\text { extract }\end{array}$ & $\begin{array}{l}\text { Anthocyanin and } \\
\text { proanthocyanidin }\end{array}$ & $\begin{array}{l}\text { Rotenone treated } \\
\text { dopaminergic cell }\end{array}$ & $\begin{array}{l}\text { Blackcurrant extract alleviated } \\
\text { neurodegeneration in Parkin- } \\
\text { son's disease via enhancement } \\
\text { of mitochondrial function }\end{array}$ & $\begin{array}{l}\text { Strathearn., et } \\
\text { al. [127] }\end{array}$ \\
\hline $\begin{array}{l}\text { Hypocholester- } \\
\text { olemic effect }\end{array}$ & $\begin{array}{c}\text { Blackcurrant } \\
\text { extract }\end{array}$ & Anthocyanins & Caco- 2 cells model & $\begin{array}{c}\text { Blackcurrant extract modulated } \\
\text { genes involved in intestinal } \\
\text { cholesterol transport }\end{array}$ & Kim., et al. [64] \\
\hline $\begin{array}{l}\text { Antibacterial } \\
\text { effect }\end{array}$ & $\begin{array}{c}\text { Blackcurrant } \\
\text { extract }\end{array}$ & Anthocyanins & $\begin{array}{l}\text { Listeria mono- } \\
\text { cytogenes and } \\
\text { other food-spoiling } \\
\text { bacteria }\end{array}$ & $\begin{array}{l}\text { Anthocyanin-rich berries would } \\
\text { have potential as both antibac- } \\
\text { terial additives in food }\end{array}$ & $\begin{array}{l}\text { Raudsepp., et al. } \\
{[114]}\end{array}$ \\
\hline $\begin{array}{l}\text { Hypoglycemic } \\
\text { effects }\end{array}$ & $\begin{array}{c}\text { Blackcurrant } \\
\text { extract }\end{array}$ & $\begin{array}{l}\text { Anthocyanins and } \\
\text { their acid hydroly- } \\
\text { sates (anthocyani- } \\
\text { dins) }\end{array}$ & $\begin{array}{l}\text { In vitro enzymes } \\
\text { inhibitory activities } \\
\text { assay }\end{array}$ & $\begin{array}{l}\text { Anthocyanidins had a bet- } \\
\text { ter } \alpha \text {-glucosidase inhibitory } \\
\text { activity than their correspond- } \\
\text { ing anthocyanins after acid } \\
\text { hydrolysis }\end{array}$ & $\begin{array}{l}\text { Zhang., et al. } \\
\text { [156] }\end{array}$ \\
\hline \multirow{2}{*}{$\begin{array}{l}\text { Cardiovascular } \\
\text { protection }\end{array}$} & $\begin{array}{l}\text { Blackcurrant } \\
\text { juices }\end{array}$ & $\begin{array}{l}\text { Total polyphenol } \\
\text { content and/or } \\
\text { individual phenolic } \\
\text { compound contents }\end{array}$ & $\begin{array}{l}\text { Rat aorta segments } \\
\text { immersed in an } \\
\text { organ bath }\end{array}$ & $\begin{array}{l}\text { Blackcurrant juice caused the } \\
\text { most marked vasorelaxation. } \\
\text { Kaempferol, epigallocatechin } \\
\text { gallate and peonidin-3-0- } \\
\text { glucoside seemed to emerge as } \\
\text { the interesting phenolic com- } \\
\text { pounds likely to be responsible } \\
\text { for the potent vasorelaxation }\end{array}$ & $\begin{array}{l}\text { Matute., et al. } \\
\qquad[86]\end{array}$ \\
\hline & $\begin{array}{l}\text { Blackcurrant } \\
\text { extract and antho- } \\
\text { cyanins }\end{array}$ & $\begin{array}{l}\text { Blackcurrant extract } \\
\text { and anthocyanins }\end{array}$ & $\begin{array}{l}\text { The effects of black- } \\
\text { currant extract on } \\
\text { the regulation of } \\
\text { eNOS expression } \\
\text { and NO synthesis in } \\
\text { human endothelial } \\
\text { cells as key regula- } \\
\text { tors in cardiovascu- } \\
\text { lar disease }\end{array}$ & $\begin{array}{c}\text { Blackcurrant extract and } \\
\text { anthocyanin may regulate NO } \\
\text { synthesis via eNOS expression. }\end{array}$ & $\begin{array}{l}\text { Horie., et al. } \\
\qquad[52]\end{array}$ \\
\hline
\end{tabular}

Citation: Xin Shao, Gang Wu., et al. "Bioactivity, Bioavailability and Bioaccessibility of Blackcurrant Anthocyanins: An Updated Comprehensive Review". 
21

\begin{tabular}{|c|c|c|c|c|c|}
\hline Main benefits & Materials & Effective factors & Methods & Conclusions & Reference \\
\hline \multirow[t]{6}{*}{$\begin{array}{l}\text { Anti-inflamma- } \\
\text { tion }\end{array}$} & $\begin{array}{l}\text { Blackcurrant } \\
\text { juice }\end{array}$ & $\begin{array}{l}\text { Anthocyanins and } \\
\text { ascorbic acid }\end{array}$ & $\begin{array}{c}\text { RAW } 264.7 \text { macro- } \\
\text { phages }\end{array}$ & $\begin{array}{c}\text { Anthocyanins and ascorbic acid } \\
\text { in blackcurrant juice repressed } \\
\text { inflammatory biomarkers }\end{array}$ & $\begin{array}{l}\text { Huebbe., et } \\
\text { al. [53] }\end{array}$ \\
\hline & $\begin{array}{c}\text { Blackcurrant } \\
\text { extract }\end{array}$ & $\begin{array}{l}\text { Delphinidin-3-ru- } \\
\text { tinoside (44\%) }\end{array}$ & $\begin{array}{c}\text { RAW } 264.7 \text { macro- } \\
\text { phages }\end{array}$ & $\begin{array}{l}\text { Blackcurrant extract partly } \\
\text { inhibited nuclear translocation of } \\
\text { NF-kB independent of the Nrf2- } \\
\text { mediated pathways. }\end{array}$ & $\begin{array}{l}\text { Lee et al. } \\
\quad[71]\end{array}$ \\
\hline & $\begin{array}{c}\text { Blackcurrant } \\
\text { extract }\end{array}$ & Anthocyanins & $\begin{array}{l}\text { A two-component cell } \\
\text { culture system of intes- } \\
\text { tinal epithelial cells and } \\
\text { macrophages }\end{array}$ & $\begin{array}{l}\text { Blackcurrant extract downregu- } \\
\text { lated the expression of inflamma- } \\
\text { tory mediators }\end{array}$ & $\begin{array}{c}\text { Olejnik., et al. } \\
{[106]}\end{array}$ \\
\hline & $\begin{array}{l}\text { Purified black- } \\
\text { currant antho- } \\
\text { cyanin samples }\end{array}$ & Anthocyanins & $\begin{array}{l}\text { Human endothelial } \\
\text { cells }\end{array}$ & $\begin{array}{l}\text { Blackcurrant anthocyanins re- } \\
\text { duced the expression of endothe- } \\
\text { lial inflammatory antigens }\end{array}$ & $\begin{array}{c}\text { Blando., et al. } \\
\text { [12] }\end{array}$ \\
\hline & $\begin{array}{l}\text { Blackcurrant } \\
\text { extract }\end{array}$ & $\begin{array}{c}\text { Blackcurrant } \\
\text { extract }\end{array}$ & $\begin{array}{l}\text { Mouse bone marrow- } \\
\text { derived macrophages } \\
\text { and human THP-1 } \\
\text { macrophages }\end{array}$ & $\begin{array}{l}\text { Blackcurrant extract metabo- } \\
\text { lites inhibited the production of } \\
\text { obesity-associated inflammatory } \\
\text { factors. }\end{array}$ & Lee, Lee [74] \\
\hline & $\begin{array}{l}\text { Blackcurrant } \\
\text { enriched cook- } \\
\text { ies extract }\end{array}$ & Phenolic extracts & $\begin{array}{c}\text { Cancer cell line, HepG2 } \\
\text { model }\end{array}$ & $\begin{array}{l}\text { Phenolic extracts suppressed } \\
\text { the regulation of inflammatory } \\
\text { cytokine IL-1 } \beta \text { (about } 3 \text { to } 4 \text {-fold), } \\
\text { IL-6 (about } 2 \text {-fold) and tran- } \\
\text { scription signalling factor NF-kB } \\
\text { (about 2-fold). }\end{array}$ & $\begin{array}{l}\text { Mofasser } \\
\text { Hossain., et } \\
\text { al.. [90] }\end{array}$ \\
\hline \multirow[t]{3}{*}{ Anticancer } & $\begin{array}{c}\text { Blackcurrant } \\
\text { extract }\end{array}$ & $\begin{array}{l}\text { Phenolic com- } \\
\text { pounds }\end{array}$ & $\begin{array}{l}\text { In vitro simulated up- } \\
\text { per intestinal tract di- } \\
\text { gestion and subsequent } \\
\text { fecal fermentation }\end{array}$ & $\begin{array}{l}\text { Phenolic compounds metabolites } \\
\text { retained biological activity and } \\
\text { modulated cellular processes as- } \\
\text { sociated with colon cancer. }\end{array}$ & $\begin{array}{c}\text { Brown., et al. } \\
\text { [15] }\end{array}$ \\
\hline & $\begin{array}{l}\text { Blackcurrant } \\
\text { juice }\end{array}$ & Anthocyanins & $\begin{array}{l}\text { Murine melanoma } \\
\text { (B16F10), ovarian } \\
\text { cancer (A2780) and } \\
\text { cervical cancer (HeLa) } \\
\text { cell lines }\end{array}$ & $\begin{array}{l}\text { Blackcurrant anthocyanins } \\
\text { antioxidant potential was associ- } \\
\text { ated with their antiproliferative } \\
\text { potential }\end{array}$ & $\begin{array}{l}\text { Diaconeasa., } \\
\text { et al. }[33]\end{array}$ \\
\hline & Blackcurrant & $\begin{array}{l}\text { Blackcurrant } \\
\text { juice, blackcur- } \\
\text { rant extract and } \\
\text { anthocyanins }\end{array}$ & Jurkat cells & $\begin{array}{l}\text { The blackcurrant juice and black- } \\
\text { currant extract induced activa- } \\
\text { tion of caspase } 3 \text { was markedly } \\
\text { inhibited by pretreatment with } \\
\text { N-acetylcysteine. } \\
\text { Blackcurrant extract and the two } \\
\text { active anthocyanins induced the } \\
\text { formation of reactive oxygen } \\
\text { species. } \\
\text { Blackcurrant juice and its major } \\
\text { anthocyanins induced a redox- } \\
\text { sensitive caspase } 3 \text {-dependent } \\
\text { apoptosis in Jurkat cells, involving } \\
\text { a dysregulation of the Akt/Bad/ } \\
\text { Bcl-2 pathway }\end{array}$ & $\begin{array}{l}\text { Leon-Gon- } \\
\text { zalez., et al. } \\
\quad[76]\end{array}$ \\
\hline
\end{tabular}




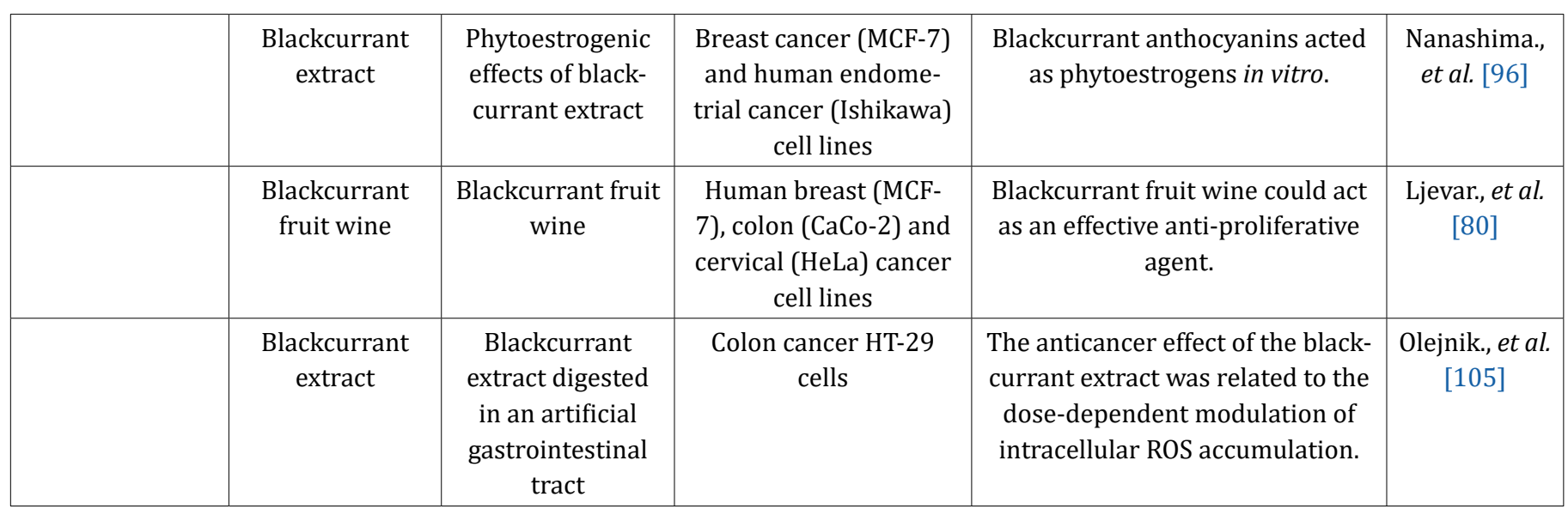

Table 3: In vitro investigations.

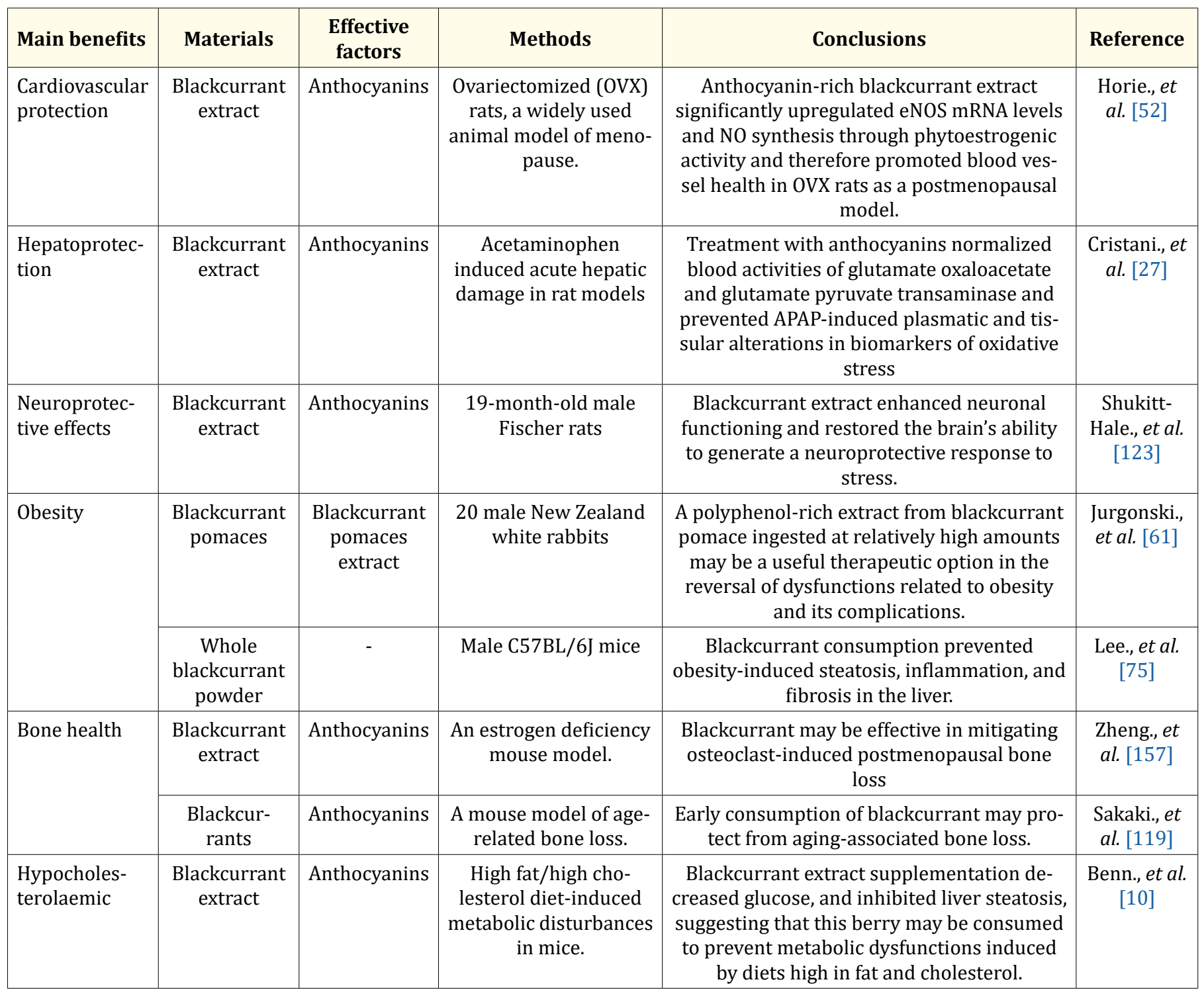




\begin{tabular}{|c|c|c|c|c|c|}
\hline & $\begin{array}{c}\text { Blackcurrant } \\
\text { pomaces }\end{array}$ & $\begin{array}{l}\text { Blackcurrant } \\
\text { pomaces } \\
\text { containing } \\
\text { variable level } \\
\text { of phenolic } \\
\text { compounds }\end{array}$ & Wistar rats & $\begin{array}{l}\text { Better hypocholesterolemia effect was } \\
\text { observed after supplementation of the diet } \\
\text { with unprocessed preparation of blackcur- } \\
\text { rant pomaces. }\end{array}$ & $\begin{array}{l}\text { Jaroslaws- } \\
\text { ka., et al. } \\
\quad[58]\end{array}$ \\
\hline & $\begin{array}{l}\text { Blackcurrant } \\
\text { pomaces }\end{array}$ & $\begin{array}{l}66.5 \% \\
\text { dietary fibers } \\
\text { and } 4.9 \% \\
\text { polyphenols }\end{array}$ & Rats fed a high-fat diet & $\begin{array}{l}\text { The 8-week supplementation with blackcur- } \\
\text { rant fiber decreased body weight, whereas } \\
\text { both fibers decreased epididymal fat mass, } \\
\text { increased the fecal concentration of short- } \\
\text { chain fatty acids, prevented hyperinsu- } \\
\text { linemia and decreased cholesterolaemia. }\end{array}$ & $\begin{array}{l}\text { Jurgonski., } \\
\text { et al. [60] }\end{array}$ \\
\hline \multirow[t]{2}{*}{$\begin{array}{l}\text { Hypoglycae- } \\
\text { mic }\end{array}$} & $\begin{array}{c}\text { Blackcurrant } \\
\text { extract }\end{array}$ & Anthocyanins & $\begin{array}{l}\text { High fat/high cho- } \\
\text { lesterol diet-induced } \\
\text { metabolic disturbances } \\
\text { in mice. }\end{array}$ & $\begin{array}{l}\text { Blackcurrant extract supplementation } \\
\text { decreased plasma total cholesterol and glu- } \\
\text { cose, and inhibited liver steatosis. }\end{array}$ & $\begin{array}{l}\text { Benn., et al. } \\
\quad[10]\end{array}$ \\
\hline & $\begin{array}{c}\text { Blackcurrant } \\
\text { extract }\end{array}$ & $\begin{array}{l}\text { Delphinidin } \\
\text { 3-rutinoside }\end{array}$ & $\begin{array}{c}\text { Type } 2 \text { diabetic mice } \\
(\mathrm{KK}-\mathrm{A}(\mathrm{y})) .\end{array}$ & $\begin{array}{l}\text { Delphinidin 3-rutinoside-rich blackcurrant } \\
\text { extract may help prevent diabetes and allow } \\
\text { the dosages of diabetes drugs to be reduced. }\end{array}$ & $\begin{array}{l}\text { Iizuka., et } \\
\text { al. [57] }\end{array}$ \\
\hline
\end{tabular}

\begin{tabular}{|c|c|c|c|c|c|}
\hline $\begin{array}{l}\text { Main } \\
\text { benefits }\end{array}$ & Materials & $\begin{array}{l}\text { Effective } \\
\text { factors }\end{array}$ & Methods & Conclusions & Reference \\
\hline \multirow[t]{2}{*}{$\begin{array}{l}\text { Anti-inflam- } \\
\text { mation }\end{array}$} & $\begin{array}{c}\text { Blackcurrant } \\
\text { extract }\end{array}$ & $\begin{array}{c}\text { Four major } \\
\text { anthocyanins }\end{array}$ & $\begin{array}{l}\text { Stimulated human } \\
\text { alveolar epithelial } \\
\text { cells. }\end{array}$ & $\begin{array}{l}\text { All blackcurrant polyphenolic extracts } \\
\text { suppressed CCL26 secretion by lung } \\
\text { alveolar cells } \\
\text { Delphinidin glycosides to cyanidin gly- } \\
\text { cosides in the blackcurrant cultivars was } \\
\text { an important determinant in influencing } \\
\text { CCL26 suppression in lung cells. } \\
\text { The development of specific cultivars as } \\
\text { functional foods/ingredients with benefi- } \\
\text { cial biological activities }\end{array}$ & $\begin{array}{l}\text { Nyanhanda., } \\
\text { et al. [101] }\end{array}$ \\
\hline & $\begin{array}{l}\text { Freeze-dried } \\
\text { blackcurrant }\end{array}$ & Anthocyanins & $\begin{array}{l}\text { A diet-induced } \\
\text { obesity (DIO) mouse } \\
\text { model. }\end{array}$ & $\begin{array}{l}\text { Blackcurrant significantly reduced F4/80 } \\
\text { mRNA and the number of CLS in the } \\
\text { epididymal fat pad, indicative of less } \\
\text { macrophage infiltration. } \\
\text { Varying anthocyanin composition differ- } \\
\text { entially affect plasma lipids and adipose } \\
\text { macrophage infiltration in DIO mice, but } \\
\text { with no differences in their antioxidant } \\
\text { capacity and anti-inflammatory potential. }\end{array}$ & $\begin{array}{l}\text { Kim., et al. } \\
\quad[65]\end{array}$ \\
\hline
\end{tabular}




\begin{tabular}{|c|c|c|c|c|c|}
\hline & Blackcurrants & Anthocyanins. & $\begin{array}{l}\text { A mouse model of } \\
\text { acute allergic lung } \\
\text { inflammation. }\end{array}$ & $\begin{array}{l}\text { Oral supplementation with New Zealand } \\
\text { blackcurrant was effective in reducing } \\
\text { lung inflammation, and highlighted the } \\
\text { potential benefit of developing cultivars } \\
\text { with specific polyphenolic profiles for the } \\
\text { creation of functional foods with desir- } \\
\text { able biological activity }\end{array}$ & $\begin{array}{c}\text { Shaw., et al. } \\
\text { [122] }\end{array}$ \\
\hline $\begin{array}{l}\text { Promoting } \\
\text { gut health }\end{array}$ & Blackcurrants & $\begin{array}{l}\text { Anthocyanin- } \\
\text { rich blackcur- } \\
\text { rant extract and } \\
\text { dietary fibers } \\
\text { individually and } \\
\text { their combina- } \\
\text { tions }\end{array}$ & $\begin{array}{l}\text { The effects of } \\
\text { anthocyanin-rich } \\
\text { blackcurrant extract } \\
\text { and dietary fibers } \\
\text { individually and their } \\
\text { combinations on } \\
\text { biomarkers of large } \\
\text { intestinal health in } \\
\text { rats. }\end{array}$ & $\begin{array}{l}\text { Blackcurrants significantly altered the } \\
\text { bacterial populations by increasing the } \\
\text { abundance of Bacteroides-Prevotella- } \\
\text { Porphyromonas group and Lactobacillus } \\
\text { spp., while decreasing the abundance } \\
\text { of Bifidobacterium spp. and Clostridium } \\
\text { perfringens. } \\
\text { Dietary fiber increased the number of } \\
\text { goblet cells in the colon. }\end{array}$ & $\begin{array}{c}\text { Paturi., et al. } \\
{[111]}\end{array}$ \\
\hline
\end{tabular}

Table 4: In vivo (mouse) investigations.

\section{Vascular protection}

The potent vasorelaxation effects of anthocyanins-rich blackcurrant juice on porcine coronary artery rings was tested by Tabart., et al. [131]. The authors have found that blackcurrant anthocyanins induced vasorelaxation by improving the endothelial function. Most recently, Matute., et al. [86] investigated the vasorelaxation effects of anthocyanin-rich fruit juices under in vitro experimental conditions and highlighted that blackcurrant peonidin-3-0glucoside was probably responsible for powerful vasorelaxation.
Further clinical studies are required to properly explore the favorable endothelium-dependent cardiovascular benefits after the consumption of vegetable and fruit juice.

\section{Hypoglycemic effects}

The treatment of diabetes mellitus could benefit from a diet rich in delphinidin and/or cyanidin. Mofasser Hossain., et al. [91] added blackcurrant powder, which is high in anthocyanins, to cookies, and it was found that reduced sugar level after in vitro digestion was 
substantial $(\mathrm{p}<0.05)$. This study has demonstrated the hypoglycemic effects of blackcurrant powder, which may be used to develop functional food, such as cookies, pasta, and other high starch matrix foods. Zhang., et al. [156] discovered the $\alpha$-glucosidase inhibition activities of blackcurrant anthocyanins and anthocyanidins. Similarly, Hui., et al. [54] reported the inhibitory activities of blackcurrant powder extract towards $\alpha$-amylase and $\alpha$-glucosidase. More precisely, Hui., et al. [54] also concluded that the inhibition of Cya3-Glu and Del-3-Glu from blackcurrant powder extract exhibited stronger inhibitory activities towards $\alpha$-amylase and $\alpha$-glucosidase when compared to Mal-3-Glu and Cya-3-Rut.

\section{Anticancer effects}

Blackcurrant polyphenol breakdown products and metabolites are beneficial against colon cancer, as Brown., et al. [15] reported. Olejnik., et al. [105] further explored the anticancer effects of blackcurrant fruits on colorectal cancer cell line. The gastrointestinal digested blackcurrant extract could still deliver a variety of biological effects, including suppression of cancer cell proliferation, cancer cell cycle arrest, and induction of apoptosis, as well as a reduction in MMP-2 and MMP-9 activities that reduces cancer cell invasion. Diaconeasa., et al. [33] indicated that blackcurrant extract rich in anthocyanin might potentially inhibit the proliferation of tumor cell lines. Leon-Gonzalez., et al. [76] have further studied the blackcurrant antiproliferative effect on Jurkat cells at molecule levels and the precise mechanism. The growth of Jurkat cells was suppressed by blackcurrant-derived products and anthocyanins in a redox-sensitive fashion by triggering apoptosis through the activation of p73 and caspase 3, and the downregulation of UHRF1, which altered the p-Akt/ p-Bad/Bcl-2 pathway. One of the factors responsible for the pro-apoptotic action is the delphinidin-3-0glucoside and delphinidin-3-0- rutinoside, and its significantly dependent on a prooxidant event. Blackcurrant wine has found to be anti-proliferative tested cancer cells [80]. In addition, Nanashima., et al. [95] reported that blackcurrant extract had the potential to prevent breast cancer at gene level.

\section{Anti-inflammatory effect}

A hydroalcoholic blackcurrant extract (Ribes nigrum) has been reported to exhibit considerable anti-inflammatory efficacy without its ulcerative potential, even at high doses during chronic treatment [32]. In rats, the anti-inflammatory effect of the ethanol Ribes nigrum extract was obtained by the conventional anti-inflammatory medication indomethacin on carrageen-induced hind leg edema. Interestingly, none of the 10 extract-treated rats developed stom- ach ulcers for 21 days. Proanthocyanidins are also known to have anti-inflammatory properties [67].

\section{In vivo - Animal studies}

Table 4 depicts the various putative health benefits of blackcurrant using the in vivo investigation. Rich anthocyanins in berries might dramatically upregulate eNOS mRNA levels and NO synthesis along with phytoestrogenic activity in OVX rats as a postmenopausal model [51]. Anthocyanin-rich in blackcurrant may offer health advantages in postmenopausal women in the blood vessels. Another study utlizing an in vivo model of coronary occlusion and reperfusion has shown that rats who had a diet rich in anthocyanin have decreased infarct in their hearts (with Cy and Pg glycosides) [82]. Greater levels of myocardial glutathione and higher endogenous cardiac antioxidant defense systems might be associated with the observed cardio-protection.

The liver affects the metabolic removal of toxic substances that cause damage and decreased liver function. Anthocyanin-rich diet substantially lowered liver malondialdehyde levels, elevated the antioxidant enzyme, e.g., superoxide dismutase, and eliminated enhanced indicators of liver damage, i.e., alanine and aspartate aminotransferase [9]. Anthocyanins normalized blood activities of glutamate oxaloacetate and glutamate pyruvate transaminase, as well as prevented acetaminophen-induced plasmatic and tissue changes in biomarkers of oxidative stress [27]. Furthermore, blueberry anthocyanins reduced the production of reactive oxygen species (ROS) and oxidative tissue damage, as well as suppressed the activity of hepatic stellate cells.

Anthocyanins and anthocyanidins also exert neuroprotective activities. Anthocyanins improve neuronal function and restore the capacity of the brain to create neuroprotective stress response [123]. Anthocyanins can have effects in rats treated with D-galactose (D-gal). A lower receptor for advanced glycation end products (RAGE), decreased oxidative stress. Lower levels of inflammatory markers were produced by anthocyanins [9]. Therefore, under ischemic brain damage, the role of the anthocyanins becomes more important to provide neuroprotection instead of antioxidant properties of anthocyanins.

\section{Encapsulation of blackcurrant anthocyanins}

Blackcurrant anthocyanins are compounds that sensitive to external factors and interactions with food components such as 
enzymes pigment stability, sugars, co-pigments, and ascorbic acid, due to their chemical structure [25]. The color and stability of anthocyanins are dependent on $\mathrm{pH}$, due to changes in the concentration of the four species, including chalcone, pseudo base, flavylium cation, and quinonoid base. Besides, oxidation, light, metal ions, oxygen, temperature, acylation, and enzymes are factors that affect the rate of decomposition of anthocyanin [11,152]. Several recent studies have shown that the human digestive system can absorb intact anthocyanins in the blood and are beneficial to human health by reducing the risk of cardiovascular disease and improving vision [25]. In order to maintain the physical and chemical properties of the anthocyanin complex, providing controlled release of the functional ingredients in the human body, and building a functional barrier between the anthocyanins and external environmental factors such as light, water, reactive compounds, oxygen, heat, and enzyme, it was necessary to encapsulate the anthocyanins [152]. One of the most widely used methods for encapsulating anthocyanins is the drying method. There are also other techniques such as complexation, liposomal encapsulation, emulsification, and gelation. The drying method includes two types, the first is spray drying, where low particles are used in water activities and have wall matrices that slow down the decomposition of anthocyanins in the presence of moisture, heat, and light such as maltodextrin, modified starch, gums, proteins, and their mixtures and contains. This method applies to biopolymers, polymeric compounds, and metal ions. The proteins have high surface activity properties, which ensure the stability of anthocyanins during spray drying by forming a glass film around the particles. Another example, spray-dried pectin molecules with a high degree of esterification showed higher stabilizing effects on anthocyanins [153]. The second, freeze-drying, is a suitable encapsulation method for heat-sensitive bioactive such as anthocyanins. many works compared this method with spray drying one. The results showed that the lyophilized particles confer higher and more stable antioxidant activity for anthocyanins. However, this method still has limitations, which are presented by the higher permeability of the lyophilized particles generated by ice sublimation during the freeze-drying process, and the difficulty of controlling the particle size due to grinding or clumping of the material after drying technique [108]. Each encapsulation technique has advantages and disadvantages in relation to the applicable equipment, the feasibility of large-scale production, preparation conditions, and encapsulation wall materials. Some studies revealed that the encapsulation could impair the color quality of anthocyanins, owing to the thick encapsulated outer walls, the in- teractions between encapsulating agents, as well as the increased turbidity derived from emulsion-based delivery systems. There is still an urgent need to develop new strategies to manufacture robust delivery systems for anthocyanins, which can not only improve the color stability but also maintain food matrix quality [153]. Incorporating pigmentation and encapsulation may overcome the limitations of using a single technique. It has been shown that the combined use of fitting agents and encapsulation agents enables the simultaneous achievement of color intensification, and higher encapsulation [6]. The development of these strategies is necessary to meet consumer demand for both health awareness and benefits to achieve sustainable food engineering.

\section{Concluding remarks and future perspectives}

This study provides an insight into the bioavailability and biokinetics of blackcurrant anthocyanins, with specific emphasis on its implications in metabolic diseases. The main approach of this review is focusing on the metabolism of the anthocyanins from the blackcurrant, including the bioavailability, bioaccessibility, and bioactivity, by summarizing factors affecting phytochemical profiles of blackcurrant-based products, including growing and processing and biokinetic of blackcurrant anthocyanins. Anthocyanin absorption into the human body has been examined following intake of high-fat meals along with ground freeze-dried blackcurrant. However, in humans and animals, the absorption rate of total or individual anthocyanins was estimated to be extremely low because there were differences in the degree of anthocyanin processing of fruit product, and/or differences in diets supplemented by anthocyanin rich matter. Therefore, anthocyanins need to be biotransformed to anthocyanin-flavan-3-ols conjugates before consumption. In addition, the biotransformation of anthocyanins in vitro and living cells is important to assess the bioavailability of blackcurrant anthocyanins to optimize their health promotion effectiveness. Further studies using metabolites of anthocyanins are required for the comprehensive characterization of biokinetics of anthocyanins. Furthermore, the involvement of practical food processing, food matrices, and food digestion processes need to be taken into consideration.

\section{Acknowledgements}

We thank supports from Foundation for Distinguished Young Talents in Higher Education of Guangdong, China (No. 2018KQNCX306). 


\section{Conflicts of Interest}

There are none to declare.

\section{Bibliography}

1. Abreu IN., et al. "Quantitative trait loci mapping of polyphenol metabolites in blackcurrant (Ribes nigrum L.)". Metabolomics 16 (2020): 23.

2. Allwood JW., et al. "Application of HPLC-PDA-MS metabolite profiling to investigate the effect of growth temperature and day length on blackcurrant fruit". Metabolomics 15 (2019): 17.

3. Angelino D., et al. "Bioaccessibility and bioavailability of phenolic compounds in bread: a review". Food and Function 8 (2017): 2368-2393.

4. Archaina D., et al. "Physical and functional properties of spraydried powders from blackcurrant juice and extracts obtained from the waste of juice processing". Food Science and Technology International 24 (2018): 78-86.

5. Azman EM., et al. "Effect of dehydration on phenolic compounds and antioxidant activity of blackcurrant (Ribes nigrum L.) pomace". International Journal of Food Science and Technology 56 (2020): 600-607.

6. Bakowska-Barczak AM and Kolodziejczyk PP. "Black currant polyphenols: Their storage stability and microencapsulation". Industrial Crops and Products 34 (2011): 1301-1309.

7. Basegmez HIO., et al. "Biorefining of blackcurrant pomace into high value functional ingredients using supercritical $\mathrm{CO} 2$, pressurized liquid and enzyme assisted extractions". The Journal of Supercritical Fluids 124 (2017): 10-19.

8. Bender C., et al. "Effect of mash enzyme and heat treatments on the cellular antioxidant activity of black currant (Ribes nigrum), raspberry (Rubus idaeus), and blueberry (Vaccinium myrtillus) juices". CyTA - Journal of Food 15 (2017): 277-283.

9. Bendokas V., et al. "Anthocyanins: From the Field to the Antioxidants in the Body". Antioxidants 9 (2020): 819.

10. Benn T., et al. "Polyphenol-rich blackcurrant extract exerts hypocholesterolaemic and hypoglycaemic effects in mice fed a diet containing high fat and cholesterol". British Journal of Nutrition 113 (2015): 1697-1703.

11. Bishayee A., et al. "Anthocyanin-rich black currant (Ribes nigrum L.) extract affords chemoprevention against diethylnitrosamine-induced hepatocellular carcinogenesis in rats". The Journal of Nutritional Biochemistry 22 (2011): 1035-1046.
12. Blando F., et al. "Radical Scavenging and Anti-Inflammatory Activities of Representative Anthocyanin Groupings from Pigment-Rich Fruits and Vegetables". International Journal of Molecular Sciences 19 (2018): 15.

13. Braakhuis AJ., et al. "The effect of New Zealand blackcurrant on sport performance and related biomarkers: a systematic review and meta-analysis". Journal of the International Society of Sports Nutrition 17 (2020): 10.

14. Brenes CH., et al. "Stability of Copigmented Anthocyanins and Ascorbic Acid in a Grape Juice Model System". Journal of Agricultural and Food Chemistry 53 (2005): 49-56.

15. Brown EM., et al. "Persistence of Anticancer Activity in Berry Extracts after Simulated Gastrointestinal Digestion and Colonic Fermentation". PLoS One 7 (2012): 10.

16. Cao L., et al. "Long-Term Blackcurrant Supplementation Modified Gut Microbiome Profiles in Mice in an Age-Dependent Manner: An Exploratory Study". Nutrients 12 (2020): 13.

17. Carbonell-Capella JM., et al. "Quality parameters, bioactive compounds and their correlation with antioxidant capacity of commercial fruit-based baby foods". Food Science and Technology International 20 (2014): 479-487.

18. Castro-Acosta ML., et al. "Drinks containing anthocyanin-rich blackcurrant extract decrease postprandial blood glucose, insulin and incretin concentrations". Journal of Nutritional Biochemistry 38 (2016): 154-161.

19. Castro-Acosta ML., et al. "Apple and blackcurrant polyphenolrich drinks decrease postprandial glucose, insulin and incretin response to a high-carbohydrate meal in healthy men and women". The Journal of Nutritional Biochemistry 49 (2017): 53-62.

20. Castro-Acosta ML., et al. "Apple and blackcurrant polyphenolrich drinks decrease postprandial glucose, insulin and incretin response to a high-carbohydrate meal in healthy men and women". Journal of Nutritional Biochemistry 49 (2017): 53-62.

21. Charron CS., et al. "Bioavailability of Anthocyanins from Purple Carrot Juice: Effects of Acylation and Plant Matrix". Journal of Agricultural and Food Chemistry 57 (2009): 1226-1230.

22. Cook MD., et al. "Cardiovascular function during supine rest in endurance-trained males with New Zealand blackcurrant: a dose-response study". European Journal of Applied Physiology 117 (2017): 247-254. 
23. Cook MD., et al. "Cardiovascular function during supine rest in endurance-trained males with New Zealand blackcurrant: a dose-response study". European Journal of Applied Physiology 117 (2017): 247-254.

24. Cook MD., et al. "Dose effects of New Zealand blackcurrant on substrate oxidation and physiological responses during prolonged cycling". European Journal of Applied Physiology 117 (2017): 1207-1216.

25. Cook MD., et al. "Blackcurrant Alters Physiological Responses and Femoral Artery Diameter during Sustained Isometric Contraction". Nutrients 9 (2017): 14.

26. Cortez RE., et al. "Blackcurrants (Ribes nigrum): A Review on Chemistry, Processing, and Health Benefits". Journal of Food Science 84 (2019): 2387-2401.

27. Cristani M., et al. "Protective activity of an anthocyanin-rich extract from bilberries and blackcurrants on acute acetaminophen-induced hepatotoxicity in rats". Natural Product Research 30 (2016): 2845-2849.

28. Crozier A., et al. "Dietary phenolics: chemistry, bioavailability and effects on health". Natural Product Reports 26 (2009): 1001-1043.

29. David SG., et al. "Laboratory and clinical studies of cancer chemoprevention by antioxidants in berries". Carcinogenesis 29 (2008): 1665-1674.

30. De Pascual-Teresa S and Sanchez-Ballesta MT. "Anthocyanins: from plant to health". Phytochemistry Reviews 7 (2008): 281299.

31. De Rosso VV and Mercadante AZ. "The high ascorbic acid content is the main cause of the low stability of anthocyanin extracts from acerola”. Food Chemistry 103 (2007): 935-943.

32. Declume C. "Anti-inflammatory evaluation op a hydroalcoholic extract op black currant leaves (Ribes nigrum)". Journal of Ethnopharmacology 27 (1989): 91-98.

33. Diaconeasa Z., et al. "Antiproliferative and Antioxidant Properties of Anthocyanin Rich Extracts from Blueberry and Blackcurrant Juice". International Journal of Molecular Sciences 16 (2015): 2352-2365.

34. Dima C., et al. "Bioavailability and bioaccessibility of food bioactive compounds; overview and assessment by in vitro methods". Comprehensive Reviews in Food Science and Food Safety 19 (2020): 2862-2884.
35. Drakou CE., et al. "Affinity Crystallography Reveals Binding of Pomegranate Juice Anthocyanins at the Inhibitor Site of Glycogen Phosphorylase: The Contribution of a Sugar Moiety to Potency and Its Implications to the Binding Mode". Journal of Agricultural and Food Chemistry 68 (2020): 10191-10199.

36. Dreiseitel A., et al. "Berry anthocyanins and anthocyanidins exhibit distinct affinities for the efflux transporters BCRP and MDR1". British Journal of Pharmacology 158 (2009): 19421950.

37. Espín JC., et al. "Nutraceuticals: Facts and fiction". Phytochemistry 68 (2007): 2986-3008.

38. Fan DW., et al. "Supplementation of Blackcurrant Anthocyanins Increased Cyclic Glycine-Proline in the Cerebrospinal Fluid of Parkinson Patients: Potential Treatment to Improve Insulin-Like Growth Factor-1 Function". Nutrients 10 (2018): 11.

39. Faria A., et al. "Absorption of anthocyanins through intestinal epithelial cells - Putative involvement of GLUT2". Molecular Nutrition and Food Research 53 (2009): 1430-1437.

40. Farooque S., et al. "Enhancing the Potential Exploitation of Food Waste: Extraction, Purification, and Characterization of Renewable Specialty Chemicals from Blackcurrants (Ribes nigrum L.)". Journal of Agricultural and Food Chemistry 66 (2018): 12265-12273.

41. Gagneten M., et al. "Spray-dried powders from berries extracts obtained upon several processing steps to improve the bioactive components content". Powder Technology 342 (2019): 1008-1015.

42. Gagneten M., et al. "Optimization of Pulsed Electric Field Treatment for the Extraction of Bioactive Compounds from Blackcurrant". Food and Bioprocess Technology 12 (2019): 1102-1109.

43. Garzón GA and Wrolstad RE. "Comparison of the Stability of Pelargonidin-based Anthocyanins in Strawberry Juice and Concentrate". Journal of Food Science 67 (2002): 1288-1299.

44. Godwin C., et al. "Effect of New Zealand Blackcurrant Extract on Performance during the Running Based Anaerobic Sprint Test in Trained Youth and Recreationally Active Male Football Players". Sports 5 (2017): 10.

45. Godwin C., et al. "Effect of New Zealand Blackcurrant Extract on Performance during the Running Based Anaerobic Sprint Test in Trained Youth and Recreationally Active Male Football Players". Sports 5 (2017): 69. 
46. Gonçalves J., et al. "Assessment of the Bioaccessibility and Bioavailability of the Phenolic Compounds of Prunus avium L. by in Vitro Digestion and Cell Model". ACS Omega 4 (2019): 76057613.

47. Gu L., et al. "Concentrations of proanthocyanidins in common foods and estimations of normal consumption". The Journal of Nutritional 134 (2004): 613-617.

48. Han F., et al. "Digestion and absorption of red grape and wine anthocyanins through the gastrointestinal tract". Trends in Food Science and Technology 83 (2019): 211-224.

49. Hélder Oliveira., et al. "Comparison of the in vitro gastrointestinal bioavailability of acylated and non-acylated anthocyanins: Purple-fleshed sweet potato vs red wine". Food Chemistry 276 (2018): 410-418.

50. Hiles AM., et al. "Dietary supplementation with New Zealand blackcurrant extract enhances fat oxidation during submaximal exercise in the heat". Journal of Science and Medicine in Sport 23 (2020): 908-912.

51. Horie K., et al. "Phytoestrogenic Effects of Blackcurrant Anthocyanins Increased Endothelial Nitric Oxide Synthase (eNOS) Expression in Human Endothelial Cells and Ovariectomized Rats". Molecules 24 (2019): 1259.

52. Horie K., et al. "Phytoestrogenic Effects of Blackcurrant Anthocyanins Increased Endothelial Nitric Oxide Synthase (eNOS) Expression in Human Endothelial Cells and Ovariectomized Rats". Molecules 24 (2019): 11.

53. Huebbe P., et al. "Effects of blackcurrant-based juice on atherosclerosis-related biomarkers in cultured macrophages and in human subjects after consumption of a high-energy meal". British Journal of Nutrition 108 (2012): 234-244.

54. Hui X., et al. "The effects of bioactive compounds from blueberry and blackcurrant powders on the inhibitory activities of oat bran pastes against $\alpha$-amylase and $\alpha$-glucosidase linked to type 2 diabetes". Food Research International 138 (2020): 109756.

55. Hurst RD., et al. "Consumption of an Anthocyanin-Rich Extract Made From New Zealand Blackcurrants Prior to Exercise May Assist Recovery From Oxidative Stress and Maintains Circulating Neutrophil Function: A Pilot Study". Frontiers in Nutrition 6 (2019): 14.
56. Hurst RD., et al. "Daily Consumption of an Anthocyanin-Rich Extract Made From New Zealand Blackcurrants for 5 Weeks Supports Exercise Recovery Through the Management of Oxidative Stress and Inflammation: A Randomized Placebo Controlled Pilot Study". Frontiers in Nutrition 7 (2020): 15.

57. Iizuka Y., et al. "Blackcurrant Extract Ameliorates Hyperglycemia in Type 2 Diabetic Mice in Association with Increased Basal Secretion of Glucagon-Like Peptide-1 and Activation of AMP-Activated Protein Kinase". Journal of Nutritional Science and Vitaminology 64 (2018): 258-264.

58. Jaroslawska J., et al. "Protective effects of polyphenol-rich blackcurrant preparation on biochemical and metabolic biomarkers of rats fed a diet high in fructose". Journal of Animal Physiology and Animal Nutrition 100 (2016): 136-145.

59. Jarret DA., et al. "A Transcript and Metabolite Atlas of Blackcurrant Fruit Development Highlights Hormonal Regulation and Reveals the Role of Key Transcription Factors". Frontiers in Plant Science 9 (2018): 22.

60. Jurgonski A., et al. "Diet-induced disorders in rats are more efficiently attenuated by initial rather than delayed supplementation with polyphenol-rich berry fibres". Journal of Functional Foods 22 (2016): 556-564.

61. Jurgonski A., et al. "Polyphenol-rich extract from blackcurrant pomace attenuates the intestinal tract and serum lipid changes induced by a high-fat diet in rabbits". European Journal of Nutrition 53 (2014): 1603-1613.

62. Keppler K and Humpf H-U. "Metabolism of anthocyanins and their phenolic degradation products by the intestinal microflora". Bioorganic and Medicinal Chemistry 13 (2005): 51955205.

63. Khoo GM., et al. "Bioactivity and chemical composition of blackcurrant (Ribes nigrum) cultivars with and without pesticide treatment". Food Chemistry 132 (2012): 1214-1220.

64. Kim B., et al. "Blackcurrant anthocyanins stimulated cholesterol transport via post-transcriptional induction of LDL receptor in Caco-2 cells". European Journal of Nutrition 57 (2018): 405-415.

65. Kim B., et al. "Blueberry, blackberry, and blackcurrant differentially affect plasma lipids and pro-inflammatory markers in diet-induced obesity mice". Nutrition Research and Practice 10 (2016): 494-500. 
66. Kong J-M., et al. "Analysis and biological activities of anthocyanins". Phytochemistry 64 (2003): 923-933.

67. Kontiokari T., et al. "Cranberry juice and bacterial colonization in childrenand\#x2014;A placebo-controlled randomized trial". Clinical Nutrition 24 (2005): 1065-1072.

68. Laaksonen 0., et al. "Impact of storage on sensory quality of blackcurrant juices prepared with or without enzymatic treatment at industrial scale". European Food Research and Technology (2020): 10.

69. Laaksonen OA., et al. "Chemical-Sensory Characteristics and Consumer Responses of Blackcurrant Juices Produced by Different Industrial Processes". Food and Bioprocess Technology 7 (2014): 2877-2888.

70. Laaksonen OA., et al. "Proanthocyanidins and Their Contribution to Sensory Attributes of Black Currant Juices". Journal of Agricultural and Food Chemistry 63 (2015): 5373-5380.

71. Lee SG., et al. "Berry anthocyanins suppress the expression and secretion of proinflammatory mediators in macrophages by inhibiting nuclear translocation of NF-kappa B independent of NRF2-mediated mechanism". Journal of Nutritional Biochemistry 25 (2014): 404-411.

72. Lee SG., et al. "Contribution of Anthocyanin Composition to Total Antioxidant Capacity of Berries". Plant Foods for Human Nutrition 70 (2015): 427-432.

73. Lee SG., et al. "Evaluation of $\mathrm{pH}$ differential and HPLC methods expressed as cyanidin-3-glucoside equivalent for measuring the total anthocyanin contents of berries". Journal of Food Measurement and Characterization 10 (2016): 562-568.

74. Lee Y and Lee JY. "Blackcurrant (Ribes nigrum) Extract Exerts an Anti-Inflammatory Action by Modulating Macrophage Phenotypes". Nutrients 11 (2019): 11.

75. Lee Y., et al. "Blackcurrant (Ribes nigrum) Prevents ObesityInduced Nonalcoholic Steatohepatitis in Mice". Obesity 27 (2019): 112-120.

76. Leon-Gonzalez AJ., et al. "Delphinidin-3-0-glucoside and delphinidin-3-0-rutinoside mediate the redox-sensitive caspase 3-related pro-apoptotic effect of blackcurrant juice on leukaemia Jurkat cells". Journal of Functional Foods 17 (2015): 847856.

77. Levy R., et al. "The Influence of Chemical Structure and the Presence of Ascorbic Acid on Anthocyanins Stability and Spectral Properties in Purified Model Systems". Foods 8 (2019): 207.
78. Li XR., et al. "An efficient homogenate-microwave-assisted extraction of flavonols and anthocyanins from blackcurrant marc: Optimization using combination of Plackett-Burman design and Box-Behnken design". Industrial Crops and Products 94 (2016): 834-847.

79. Liu Y., et al. "Proanthocyanidin synthesis in Theobroma cacao: genes encoding anthocyanidin synthase, anthocyanidin reductase, and leucoanthocyanidin reductase". BMC Plant Biology 13 (2013): 202.

80. Ljevar A., et al. "Phenolic Composition, Antioxidant Capacity and in vitro Cytotoxicity Assessment of Fruit Wines". Food Technology and Biotechnology 54 (2016): 145-155.

81. Manach C., et al. "Bioavailability and bioefficacy of polyphenols in humans. I. Review of 97 bioavailability studies1,2,3". The American Journal of Clinical Nutrition 81 (2005): 230S242S.

82. Marie-Claire Toufektsian., et al. "Chronic Dietary Intake of Plant-Derived Anthocyanins Protects the Rat Heart against Ischemia-Reperfusion Injury". The Journal of Nutrition 138 (2008): 747-752.

83. Matsumoto H., et al. "Ingested Delphinidin-3-rutinoside Is Primarily Excreted to Urine as the Intact Form and to Bile as the Methylated Form in Rats". Journal of Agricultural and Food Chemistry 54 (2006): 578-582.

84. Mattila PH., et al. "High variability in flavonoid contents and composition between different North-European currant (Ribes spp.) varieties". Food Chemistry 204 (2016): 14-20.

85. Mattioli R., et al. "Anthocyanins: A Comprehensive Review of Their Chemical Properties and Health Effects on Cardiovascular and Neurodegenerative Diseases". Molecules 25 (2020): 3809.

86. Matute A., et al. "Compared Phenolic Compound Contents of 22 Commercial Fruit and Vegetable Juices: Relationship to ExVivo Vascular Reactivity and Potential In Vivo Projection". Antioxidants 9 (2020): 18.

87. Mazza G., et al. "Absorption of Anthocyanins from Blueberries and Serum Antioxidant Status in Human Subjects". Journal of Agricultural and Food Chemistry 50 (2002): 7731-7737.

88. McGhie TK and Walton MC. "The bioavailability and absorption of anthocyanins: Towards a better understanding". Molecular Nutrition and Food Research 51 (2007): 702-713. 
89. Michalska A., et al. "Functional relationships between phytochemicals and drying conditions during the processing of blackcurrant pomace into powders". Advanced Powder Technology 28 (2017): 1340-1348.

90. Mofasser Hossain AKM., et al. "Cellular biological activity and regulation of gene expression of antioxidant dietary fibre fraction isolated from blackcurrant incorporated in the wholemeal cereals cookies". Food Chemistry 312 (2020): 125829.

91. Mofasser Hossain AKM., et al. "The Combined Effect of Blackcurrant Powder and Wholemeal Flours to Improve Health Promoting Properties of Cookies". Plant Foods and Hum Nutrition 72 (2017): 280-287.

92. Moskaug JØ., et al. "Dietary polyphenols identified as intracellular protein kinase A inhibitors". European Journal of Nutrition 47 (2008): 460-469.

93. Murphy CA., et al. "Effect of New Zealand Blackcurrant Extract on Repeated Cycling Time Trial Performance". Sports 5 (2017): 6.

94. Murphy CA., et al. "Effect of New Zealand Blackcurrant Extract on Repeated Cycling Time Trial Performance". Sports 5 (2017): 25.

95. Nanashima N., et al. "Anthocyanin-rich blackcurrant extract inhibits proliferation of the MCF10A healthy human breast epithelial cell line through induction of G0/G1 arrest and apoptosis". Molecular Medicine Reports 16 (2017): 6134-6141.

96. Nanashima N., et al. "Phytoestrogenic activity of blackcurrant (Ribes nigrum) anthocyanins is mediated through estrogen receptor alpha". Molecular Nutrition and Food Research 59 (2015): 2419-2431.

97. Neri-Numa IA., et al. "Natural prebiotic carbohydrates, carotenoids and flavonoids as ingredients in food systems". Current Opinion in Food Science 33 (2020): 98-107.

98. Nolan A., et al. "Short-term, but not acute, intake of New Zealand blackcurrant extract improves insulin sensitivity and free-living postprandial glucose excursions in individuals with overweight or obesity". European Journal of Nutrition (2020): 10.

99. Norberto S., et al. "Blueberry anthocyanins in health promotion: A metabolic overview". Journal of Functional Foods 5 (2013): 1518-1528.
100. Nour V., et al. "Anthocyanins profile, total phenolics and antioxidant activity of black currant ethanolic extracts as influenced by genotype and ethanol concentration". Food and Function 141 (2013): 961-966.

101. Nyanhanda T., et al. "Blackcurrant cultivar polyphenolic extracts suppress CCL26 secretion from alveolar epithelial cells". Food and Function 5 (2014): 671-677.

102. Okamoto T., et al. "Effects of blackcurrant extract on arterial functions in older adults: A randomized, double-blind, placebo-controlled, crossover trial". Clinical and Experimental Hypertension (2020): 8.

103. Okatan V. "Antioxidant properties and phenolic profile of the most widely appreciated cultivated berry species: A comparative study". Folia Horticulturae 32 (2020): 79-85.

104. Oktar S., et al. "The relationship between phthalates and obesity: Serum and urine concentrations of phthalates". Minerva Endocrinologica 42 (2017): 46.

105. Olejnik A., et al. "ROS-modulating anticancer effects of gastrointestinally digested Ribes nigrum L. fruit extract in human colon cancer cells". Journal of Functional Foods 42 (2018): 224-236.

106. Olejnik A., et al. "A Gastrointestinally Digested Ribes nigrum L. Fruit Extract Inhibits Inflammatory Response in a Co-culture Model of Intestinal Caco-2 Cells and RAW264.7 Macrophages". Journal of Agricultural and Food Chemistry 64 (2016): 7710-7721.

107. Overall J., et al. "Metabolic Effects of Berries with Structurally Diverse Anthocyanins". International Journal of Molecular Sciences 18 (2017): 16.

108. Ozkan G., et al. "A review of microencapsulation methods for food antioxidants: Principles, advantages, drawbacks and applications". Food Chemistry 272 (2019): 494-506.

109. Parada J and Aguilera JM. "Food Microstructure Affects the Bioavailability of Several Nutrients". Journal of Food Science 72 (2007): R21-R32.

110. Parkar SG., et al. "In vitro studies of modulation of pathogenic and probiotic bacterial proliferation and adhesion to intestinal cells by blackcurrant juices". Journal of Functional Foods 8 (2014): 35-44.

111. Paturi G., et al. "Effects of Blackcurrant and Dietary Fibers on Large Intestinal Health Biomarkers in Rats". Plant Foods for Human Nutrition 73 (2018): 54-60. 
112. Piechowiak T and Balawejder M. "Impact of ozonation process on the antioxidant status in blackcurrant Ribes nigrum L. fruit". Journal of Berry Research 9 (2019): 575-585.

113. Potter JA., et al. "Effects of New Zealand blackcurrant extract on sport climbing performance". European Journal of Applied Physiology 120 (2020): 67-75.

114. Raudsepp P., et al. "Antibacterial and antioxidative properties of different parts of garden rhubarb, blackcurrant, chokeberry and blue honeysuckle". Journal of the Science of Food and Agriculture 99 (2019): 2311-2320.

115. Rechner AR., et al. "The metabolism of dietary polyphenols and the relevance to circulating levels of conjugated metabolites". Free Radical Biology and Medicine 36 (2002): 12291241.

116. Reissner AM., et al. "Composition and physicochemical properties of dried berry pomace". Journal of the Science of Food and Agriculture 99 (2019): 1284-1293.

117. Rose PM., et al. "Application of Anthocyanins from Blackcurrant (Ribes nigrum L.) Fruit Waste as Renewable Hair Dyes". Journal of Agricultural and Food Chemistry 66 (2018): 67906798.

118. Sadowska A., et al. "Properties and microstructure of blackcurrant powders prepared using a new method of fluidizedbed jet milling and drying versus other drying methods". CyTA- Food and Function 17 (2019): 439-446.

119. Sakaki J., et al. "Blackcurrant Supplementation Improves Trabecular Bone Mass in Young but Not Aged Mice". Nutrients 10 (2018): 12.

120. Sandhu AK., et al. "Metabolic fate of strawberry polyphenols after chronic intake in healthy older adults". Food and Function 9 (2018): 96-106.

121. Schmidt C., et al. "Blackcurrant pomace from juice processing as partial flour substitute in savoury crackers: dough characteristics and product properties". International Journal of Food Science and Technology 53 (2018): 237-245.

122. Shaw OM., et al. "Blackcurrant anthocyanins modulate CCL11 secretion and suppress allergic airway inflammation". Molecular Nutrition and Food Research 61 (2017): 7.

123. Shukitt-Hale B., et al. "Dietary supplementation with fruit polyphenolics ameliorates age-related deficits in behavior and neuronal markers of inflammation and oxidative stress". Age 27 (2005): 49-57.
124. Slimestad R and Solheim H. "Anthocyanins from Black Currants (Ribes nigrum L.)". Journal of Agricultural and Food Chemistry 50 (2002): 3228-3231.

125. Smeriglio A., et al. "Proanthocyanidins and hydrolysable tannins: occurrence, dietary intake and pharmacological effects". British Journal of Pharmacology 174 (2017): 12441262.

126. Stanys V., et al. "Management of anthocyanin amount and composition in genus Ribes using interspecific hybridisation". Scientia Horticulturae 247 (2019): 123-129.

127. Strathearn KE., et al. "Neuroprotective effects of anthocyanin- and proanthocyanidin-rich extracts in cellular models of Parkinson's disease". Brain Research 1555 (2014): 60-77.

128. Strauss JA., et al. "New Zealand blackcurrant extract enhances fat oxidation during prolonged cycling in endurancetrained females". European Journal of Applied Physiology 118 (2018): 1265-1272.

129. Strugala P., et al. "Activity of Blackcurrant and Chokeberry Extracts and Two Major Cyanidin Glycosides Against Lipid Membrane Oxidation and Their Binding Proerties to Albumin". Acta Poloniae Pharmaceutica 74 (2017): 679-687.

130. Suganyadevi P., et al. "Characterization of anthocyanin from red sorghum (Sorghum bicolor) bran by liquid chromatography-electron spray ionization mass spectrometry analysis". European Journal of Mass Spectrometry 27 (2021): 107-114.

131. Tabart J., et al. "The potency of commercial blackcurrant juices to induce relaxation in porcine coronary artery rings is not correlated to their antioxidant capacity but to their anthocyanin content". Nutrition 51-52 (2018): 53-59.

132. Talavéra S., et al. "Anthocyanins are efficiently absorbed from the stomach in anesthetized rats". The Journal of Nutrition 133 (2003): 4178-4182.

133. Tani T., et al. "Delphinidin 3-rutinoside-rich blackcurrant extract ameliorates glucose tolerance by increasing the release of glucagon-like peptide-1 secretion". Food Science and Nutrition 5 (2017): 929-933.

134. Tian Y., et al. "Compositional Diversity among Blackcurrant (Ribes nigrum) Cultivars Originating from European Countries". Journal of Agricultural and Food Chemistry 67 (2019): 5621-5633. 
135. Tomisawa T., et al. "Effects of Blackcurrant Anthocyanin on Endothelial Function and Peripheral Temperature in Young Smokers". Molecules 24 (2019): 4295.

136. Tomisawa T., et al. "Effects of Blackcurrant Anthocyanin on Endothelial Function and Peripheral Temperature in Young Smokers". Molecules 24 (2019): 10.

137. Torronen R., et al. "Postprandial glycaemic response to berry nectars containing inverted sucrose". Journal of Nutritional Science 6 (2017): 7.

138. Törrönen R., et al. "Postprandial glycaemic response to berry nectars containing inverted sucrose". Journal of Nutritional Science 6 (2017): e4.

139. Törrönen R., et al. "Fortification of blackcurrant juice with crowberry: Impact on polyphenol composition, urinary phenolic metabolites, and postprandial glycemic response in healthy subjects". Journal of Functional Foods 4 (2012): 746756.

140. Torronen R., et al. "Fortification of blackcurrant juice with crowberry: Impact on polyphenol composition, urinary phenolic metabolites, and postprandial glycemic response in healthy subjects". Journal of Functional Foods 4 (2012): 746756.

141. Trych U., et al. "The Bioaccessibility of Antioxidants in Black Currant Puree after High Hydrostatic Pressure Treatment". Molecules 25 (2020): 15.

142. Vanzo A., et al. "Uptake of grape anthocyanins into the rat kidney and the involvement of bilitranslocase". Molecular Nutrition and Food Research 52 (2008): 1106-1116.

143. Walton MC., et al. "Viscous Food Matrix Influences Absorption and Excretion but Not Metabolism of Blackcurrant Anthocyanins in Rats". Journal of Food Science 74 (2009): H22H29.

144. Walton MC., et al. "The Flavonol Quercetin-3-Glucoside Inhibits Cyanidin-3-Glucoside Absorption in Vitro". Journal of Agricultural and Food Chemistry 54 (2006): 4913-4920.

145. Wang H., et al. "Oxygen Radical Absorbing Capacity of Anthocyanins". Journal of Agricultural and Food Chemistry 45 (1997): 304-309.

146. Watson AW., et al. "Acute supplementation with blackcurrant extracts modulates cognitive functioning and inhibits monoamine oxidase-B in healthy young adults". Journal of Functional Foods 17 (2015): 524-539.
147. Watson AW., et al. "The impact of blackcurrant juice on attention, mood and brain wave spectral activity in young healthy volunteers". Nutritional Neuroscience 22 (2019): 596-606.

148. Watson AW., et al. "The pharmacodynamic profile of "Blackadder" blackcurrant juice effects upon the monoamine axis in humans: A randomised controlled trial". Nutritional Neuroscience 23 (2020): 516-525.

149. Willems ME., et al. "Beneficial Effects of New Zealand Blackcurrant Extract on Maximal Sprint Speed during the Loughborough Intermittent Shuttle Test". Sports 4 (2016): 42.

150. Willems MET., et al. "Effect of New Zealand Blackcurrant Extract on Cycling Performance and Substrate Oxidation in Normobaric Hypoxia in Trained Cyclists". Sports 7 (2019): 9.

151. Willems MET., et al. "Beneficial effects on fasting insulin and postprandial responses through 7-day intake of New Zealand blackcurrant powder". FFHD - Functional Foods in Health and Disease 7 (2017): 483-493.

152. Xiong S., et al. "Stability and antioxidant activity of black currant anthocyanins in solution and encapsulated in glucan gel". Journal of Agricultural and Food Chemistry 54 (2006): 6201.

153. Xue J., et al. "Enhanced Stability of Red-Fleshed Apple Anthocyanins by Copigmentation and Encapsulation". Journal of the Science of Food and Agriculture 99 (2018): 3381-3390.

154. Yang W., et al. "Enzymatic acylation of blackcurrant (Ribes nigrum) anthocyanins and evaluation of lipophilic properties and antioxidant capacity of derivatives". Food Chemistry 281 (2019): 189-196.

155. Yang W., et al. "Effects of Latitude and Weather Conditions on Proanthocyanidins in Blackcurrant (Ribes nigrum) of Finnish Commercial Cultivars". Journal of Agricultural and Food Chemistry 67 (2019): 14038-14047.

156. Zhang JT., et al. "Chemical compositions and alpha-glucosidase inhibitory effects of anthocyanidins from blueberry, blackcurrant and blue honeysuckle fruits". Food Chemistry 299 (2019): 11.

157. Zheng X., et al. "Anthocyanin-Rich Blackcurrant Extract Attenuates Ovariectomy-Induced Bone Loss in Mice". Journal of Medicinal Food 19 (2016): 390-397. 
158. Ziberna L., et al. "The endothelial plasma membrane transporter bilitranslocase mediates rat aortic vasodilation induced by anthocyanins". Nutrition, Metabolism, and Cardiovascular Diseases 23 (2013): 68-74.

\section{Assets from publication with us}

- Prompt Acknowledgement after receiving the article

- Thorough Double blinded peer review

- Rapid Publication

- Issue of Publication Certificate

- High visibility of your Published work

Website: www.actascientific.com/

Submit Article: www.actascientific.com/submission.php

Email us: editor@actascientific.com

Contact us: +919182824667 